\title{
Contrasting stable water isotope signals from convective and large-scale precipitation phases of a heavy precipitation event in southern Italy during HyMeX IOP 13: a modelling perspective
}

\author{
Keun-Ok Lee ${ }^{1}$, Franziska Aemisegger ${ }^{2}$, Stephan Pfahl ${ }^{2,3}$, Cyrille Flamant ${ }^{4}$, Jean-Lionel Lacour ${ }^{5}$, and \\ Jean-Pierre Chaboureau ${ }^{1}$ \\ ${ }^{1}$ Laboratoire d'Aérologie, Université de Toulouse, CNRS, UPS, Toulouse, France \\ ${ }^{2}$ Institute for Atmospheric and Climate Science, ETH Zurich, 8092 Zurich, Switzerland \\ ${ }^{3}$ Institute of Meteorology, Freie Universität Berlin, Berlin, Germany \\ ${ }^{4}$ LATMOS/IPSL, CNRS, Sorbonne Université and Université Paris-Saclay, Paris, France \\ ${ }^{5}$ Institute of Earth Sciences, University of Iceland, Reykjavik, Iceland
}

Correspondence: Keun-Ok Lee (keun-ok.lee@aero.obs-mip.fr)

Received: 26 October 2018 - Discussion started: 20 November 2018

Revised: 29 April 2019 - Accepted: 30 April 2019 - Published: 5 June 2019

\begin{abstract}
The dynamical context and moisture transport pathways embedded in large-scale flow and associated with a heavy precipitation event (HPE) in southern Italy (SI) are investigated with the help of stable water isotopes (SWIs) based on a purely numerical framework. The event occurred during the Intensive Observation Period (IOP) 13 of the field campaign of the Hydrological Cycle in the Mediterranean Experiment (HyMeX) on 15 and 16 October 2012, and SI experienced intense rainfall of $62.4 \mathrm{~mm}$ over $27 \mathrm{~h}$ with two precipitation phases during this event. The first one (P1) was induced by convective precipitation ahead of a cold front, while the second one (P2) was mainly associated with precipitation induced by large-scale uplift. The moisture transport and processes responsible for the HPE are analysed using a simulation with the isotope-enabled regional numerical model

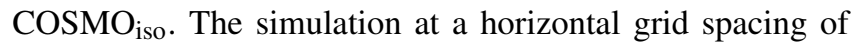
about $7 \mathrm{~km}$ over a large domain (about $4300 \mathrm{~km} \times 3500 \mathrm{~km}$ ) allows the isotopes signal to be distinguished due to local processes or large-scale advection. Backward trajectory analyses based on this simulation show that the air parcels arriving in SI during P1 originate from the North Atlantic and descend within an upper-level trough over the north-western Mediterranean. The descending air parcels reach elevations below $1 \mathrm{~km}$ over the sea and bring dry and isotopically depleted air (median $\delta^{18} \mathrm{O} \leq-25 \%$, water vapour mixing ratio $q \leq 2 \mathrm{~g} \mathrm{~kg}^{-1}$ ) close to the surface, which induces strong surface evaporation. These air parcels are rapidly enriched
\end{abstract}

in SWIs $\left(\delta^{18} \mathrm{O} \geq-14 \%\right.$ ) and moistened $\left(q \geq 8 \mathrm{~g} \mathrm{~kg}^{-1}\right)$ over the Tyrrhenian Sea by taking up moisture from surface evaporation and potentially from evaporation of frontal precipitation. Thereafter, the SWI-enriched low-level air masses arriving upstream of SI are convectively pumped to higher altitudes, and the SWI-depleted moisture from higher levels is transported towards the surface within the downdrafts ahead of the cold front over SI, producing a large amount of convective precipitation in SI. Most of the moisture processes (i.e. evaporation, convective mixing) related to the HPE take place during the $18 \mathrm{~h}$ before P1 over SI. A period of $4 \mathrm{~h}$ later, during the second precipitation phase $\mathrm{P} 2$, the air parcels arriving over SI mainly originate from north Africa. The strong cyclonic flow around the eastward-moving upperlevel trough induces the advection of a SWI-enriched African moisture plume towards SI and leads to large-scale uplift of the warm air mass along the cold front. This lifts moist and SWI-enriched air (median $\delta^{18} \mathrm{O} \geq-16 \%$, median $q \geq$ $6 \mathrm{~g} \mathrm{~kg}^{-1}$ ) and leads to gradual rain out of the air parcels over Italy. Large-scale ascent in the warm sector ahead of the cold front takes place during the $72 \mathrm{~h}$ preceding $\mathrm{P} 2$ in SI. This work demonstrates how stable water isotopes can yield additional insights into the variety of thermodynamic mechanisms occurring at the mesoscale and synoptic scale during the formation of a HPE. 


\section{Introduction}

The Mediterranean basin is frequently affected by deep convection, resulting in heavy precipitation and potentially leading to devastating flash floods. Deep convection generally results from complex multi-scale interactions between largescale, mesoscale, and microphysical processes. In the northwestern Mediterranean, the large-scale patterns associated with heavy precipitation events (HPEs) have been shown to be connected to upper-level troughs, responsible for generating low-level northward flow of marine air masses characterized by high values of equivalent potential temperature and precipitable water (Lin et al., 2001; Martius et al., 2006; Nuissier et al., 2008, 2011; Ricard et al., 2012; Barthlott and Davolio, 2015). In this favourable large-scale situation, organized deep convection can occur and often produces highimpact events, with rainfall amounts larger than $100 \mathrm{~mm}$ in less than $6 \mathrm{~h}$. The origin of the moisture feeding the convective systems is an important research topic that has been addressed using different techniques and tools, such as trajectory and numerical tracer analyses (e.g. Turato et al. 2004; Winschall et al., 2012; Duffourg and Ducrocq, 2013; Winschall et al., 2014; Röhner et al., 2016; Duffourg et al., 2018; Lee et al., 2018). These studies found substantial contributions of subtropical and tropical moisture coming from various sources such as Africa (latitude $\geq 20^{\circ} \mathrm{N}$ ) and the extratropical remnants of Atlantic tropical cyclones, among others. More recent studies (e.g. Lee et al., 2016, 2017) pointed out a significant moisture contribution, one-quarter of the total integrated water vapour, from north Africa in the middle troposphere (3-5 km above sea level, a.s.l.) feeding the deep convective systems together with the local water vapour sources over the Mediterranean in the lower troposphere (below $2 \mathrm{~km}$ a.s.l.). Moreover, the importance of intensified evaporation over the Mediterranean Sea surface for HPE has been studied (Duffourg and Ducrocq, 2013; Winschall et al., 2014). The vertical distribution of moisture in the atmosphere is shaped by source, transport, and sink processes, e.g. evaporation and condensation, horizontal and vertical advection, and turbulent and convective mixing.

To improve our understanding of the water vapour transport upstream of HPEs and the moisture cycling during such events, humidity observations based on measurements of the most abundant stable water isotope (SWI) $\mathrm{H}_{2}^{16} \mathrm{O}$ alone can be limited. In this context, the SWI observation of other, less abundant SWIs, i.e. $\mathrm{H}_{2}^{18} \mathrm{O}$ and $\mathrm{HD}^{16} \mathrm{O}$, can provide relevant additional insights (Noone et al., 2012; Pfahl et al., 2012; Aemisegger et al., 2015; Galewsky et al., 2016; Sodemann et al., 2017). Heavy and light isotopes of the water molecule are partitioned in a very specific way during phase transitions, leading to an enrichment of the heavier molecules compared to the lighter ones in the phase with the stronger bonds (liquid or ice) and a depletion in vapour. Therefore, they can provide a record of evaporation and condensation cycles along the pathway of air parcels. Moreover SWIs are a powerful indicator of phase change conditions in the atmosphere that occur during the transport of air parcels at various scales, evidencing processes such as mixing, evaporation, and condensation, since the fractionation degree follows the meteorological conditions, e.g. temperature and level of saturation (e.g. Sodemann et al., 2017). For instance, low $\delta^{2} \mathrm{H}$ (typical range between $-160 \%$ and $-180 \%$ ) or $\delta^{18} \mathrm{O}$ (i.e. range between $-20 \%$ and $-30 \%$ ) values in atmospheric water vapour at the surface indicate low air mass temperatures and strong rainout of air parcels (e.g. Jacob and Sonntag, 1991; Yoshimura et al., 2010), whereas high $\delta^{2} \mathrm{H}$ (typical range between $-120 \%$ and $-100 \%$ ) or $\delta^{18} \mathrm{O}$ (range between $-18 \%$ and $-14 \%$ ) values indicate high air mass temperatures and recent admixture of fresh ocean evaporate. The $\delta$ notation describes the concentrations of the heavy isotopes relative to the isotope ratio of the Vienna Standard Mean Ocean Water (RVSMOW), by, for instance, $\delta^{18} \mathrm{O}=$ $\left(R_{\mathrm{S}} /\right.$ RVSMOW - 1$) \times 1000$, where $R_{\mathrm{S}}=\left[\mathrm{H}_{2}^{18} \mathrm{O}\right] /\left[\mathrm{H}_{2}^{16} \mathrm{O}\right]$ is the isotope ratio of a water sample.

In the past, some of the most prominent applications of SWIs have been in a paleoclimate context to infer past temperatures and moisture sources from natural archives, for groundwater studies, and in studies investigating the water vapour budget in the stratosphere (Sherwood and Dessler, 2000; Vimeux et al., 2001; Dessler and Sherwood, 2003; Jouzel et al., 2005). The process-based insight provided by the isotope composition of atmospheric water have more recently been extended to synoptic and sub-diurnal timescales and to the lower troposphere, where most atmospheric water vapour resides. Thanks to a tremendous expansion in the number of datasets of water vapour isotopic composition and a substantially improved set of theories and models for interpreting them, the related studies have been expanded during the past several years (e.g. Pfahl et al., 2008; Steen-Larsen et al., 2014; Bonne et al. 2014; Aemisegger et al., 2015; Dütsch et al., 2018; Lacour et al., 2017; Christner et al., 2018).

Recent studies have shown unique information about meteorological processes recorded in SWI data. For instance, using ground-based SWI measurements and numerical simulations, Pfahl et al. (2012) and Aemisegger et al. (2015) investigated the mixing processes of different air masses, as well as isotope fractionation and equilibration related to precipitation evaporation during the passage of cold fronts. Aemisegger and Papritz (2018) and Aemisegger and Sjolte (2018) showed that the important moisture uptake by cold and dry airstreams during events of strong large-scale ocean evaporation carries a distinct SWI signature in water vapour. Recent studies (Schneider et al., 2016; Lacour et al., 2017) analysed the influence of the Saharan heat low on the isotopic budget of offshore west Africa on various temporal and spatial scales, highlighting the importance of the Saharan heat low dynamics on the moistening and the SWI enrichment of air parcels in the free troposphere over the North Atlantic. In addition, Risi et al. (2008) used stable isotopic signals to better understand convective precipitation 
processes. These previous studies evidenced the usefulness of water vapour isotope data to better understand meteorological processes and moisture transport. Nevertheless, there are still very few studies (Risi et al., 2008, 2010; Tremoy et al., 2014) focusing on the application of water vapour isotopes to investigate moisture processes associated with HPEs at the mesoscale, particularly in the extratropics.

SWI measurements are mainly obtained from space-borne retrievals (e.g. Schneider et al., 2016; Lacour et al., 2017) and ground-based in situ laser spectroscopy (e.g. Aemisegger et al., 2015). The space-borne measurements provide continuous datasets in space at the global scale with coarse vertical resolution and limited precision. On the other hand, groundbased measurements with high temporal resolution are only available from a few locations and from dedicated field campaigns. In particular, the data availability for the Mediterranean region is very limited. A notable exception is the airborne dataset acquired around Corsica (Sodemann et al., 2017) during the first Special Observing Period of the Hydrological cycle in the Mediterranean Experiment (HyMeX SOP-1, Ducrocq et al., 2014). However, it does not include SWI observations for the days under scrutiny in this paper. Due to these limitations we use a model to demonstrate the usefulness of SWI data for understanding moisture processes associated with a Mediterranean HPE.

Our study focuses on the transport of moisture associated with a HPE that occurred over southern Italy (SI) on 1516 October 2012 and produced precipitation over land exceeding $60 \mathrm{~mm}$ in $27 \mathrm{~h}$ (Fig. 1a). The HPE consists of two precipitation peaks, the first peak in the late afternoon of 15 October and the second peak around midnight on that day. The target HPE occurred during the Intensive Observation Period (IOP) 13 of the HyMeX SOP-1. Using a combination of ground-based, airborne, and space-borne observations and numerical simulations of this HPE, Lee et al. (2016) investigated the detailed dynamic and thermodynamic environments of the two precipitation phases of the HPE. During Phase $1(\mathrm{P} 1)$, rainfall was connected to convection triggered by local low-level convergence ahead of a cold front and was favoured by moist conditions in the lower troposphere over the Tyrrhenian Sea. Heavy precipitation during Phase 2 (P2) first occurred over Algeria and was favoured by the southerly flow ahead of the upper-level trough and high low-level moisture content and high sea surface temperatures in the Strait of Sicily. The penetration of the mistral over the Mediterranean and SI at the end of 15 October terminated the convective activity. Thanks to the unprecedented data acquired offshore and inland during IOP 13, the detailed moisture structure upstream of the HPE was investigated by Lee et al. (2016). However, the origin and transport pathways of moisture have not been studied to date.

Here we investigate these moisture transport processes using trajectory calculations and SWI data obtained from a COSMOiso numerical simulation with $7 \mathrm{~km}$ horizontal resolution with parameterized convection. This setup results from a trade-off between having high enough resolution for including detailed dynamics of the mesoscale systems and being able to run efficiently over a large domain that includes the moisture transport from Africa. More importantly, it allows the questions we are interested in to be addressed, namely the following: which isotope signals are due to local processes, and which are due to large-scale advection? A detailed description of the data and methodology is presented in Sect. 2. Section 3 provides an overview of the meteorological conditions during the two precipitation peaks related to the HPE during IOP 13. Section 4 discusses the isotope signals and relates them to the moisture transport history. A summary and a discussion of the findings of the present study are given in Sect. 5.

\section{Data and method}

\subsection{COSMOiso model configuration and simulation}

The COSMO model (Steppeler et al., 2003) is a nonhydrostatic, limited-area numerical weather and climate prediction model and is operationally used by several European weather services. The isotope implementation (COSMOiso; Pfahl et al., 2012) is similar to other Eulerian isotope models (e.g. Jaussaume et al., 1984; Sturm et al., 2005; Blossey et al., 2010). COSMOiso has already shown its capability to simulate the variations of stable water isotopes at the event timescale (Pfahl et al., 2012; Aemisegger et al., 2015) as well as in a climatological context (Christner et al., 2018; Dütsch et al., 2018). It includes two additional parallel water cycles for each of the heavy isotopes $\left(\mathrm{H}_{2}^{18} \mathrm{O}, \mathrm{HD}^{16} \mathrm{O}\right)$, which are applied only diagnostically and do not influence other components. All prognostic moisture fields, which are simulated by the model in terms of specific humidities, are duplicated twice, representing the specific humidities of $\mathrm{H}_{2}^{18} \mathrm{O}$ and $\mathrm{HD}^{16} \mathrm{O}$, respectively. From the prognostic specific humidity fields, the isotope ratios in usual $\delta$ notation can be calculated. Except during phase transition during which isotopic fractionation takes place, the heavy and light isotopes undergo identical processes. A one-moment microphysics scheme is employed, while deep convection is parameterized following Tiedtke (1989). In the microphysical scheme, transfer rates between the different water species during the formation of clouds and precipitation are specified. The heavy isotopes are affected by equilibrium fractionation during the formation of liquid clouds and both non-equilibrium and equilibrium fractionation during the formation of ice clouds (using the predicted super-saturation) as well as the re-evaporation of raindrops. For the parameterization of moist convection, all physical processes during simulated convective up- and downdrafts affect the heavy isotopes in a similar way as the standard light humidity, again taking into account equilibrium and non-equilibrium fractionation when appropriate. For more details about the physics and isotope parameteri- 
(a) Rain gauge measurement

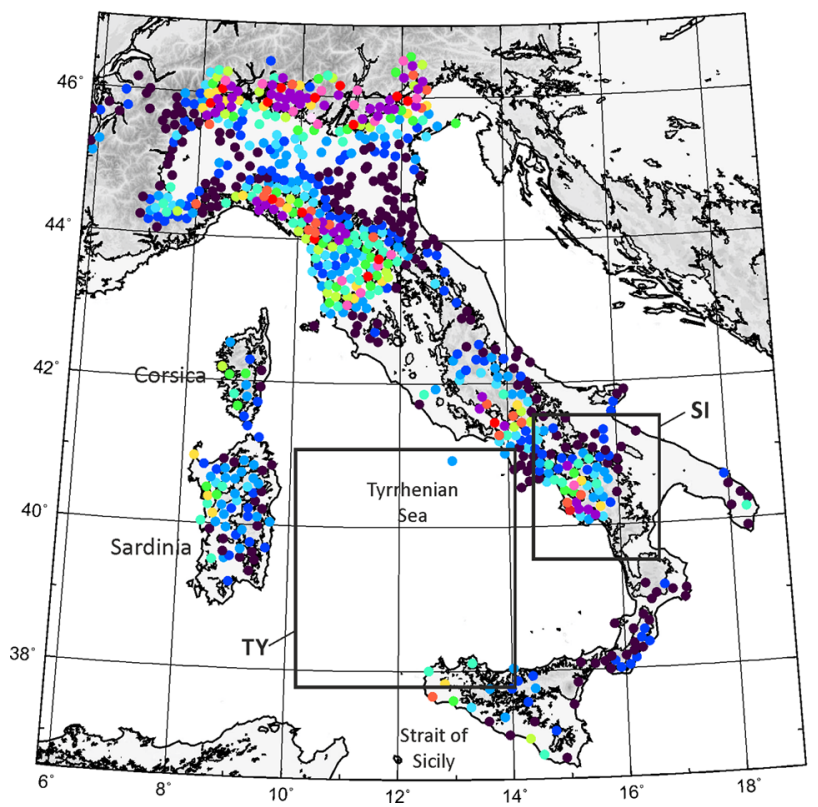

(b) COSMOiso simulation

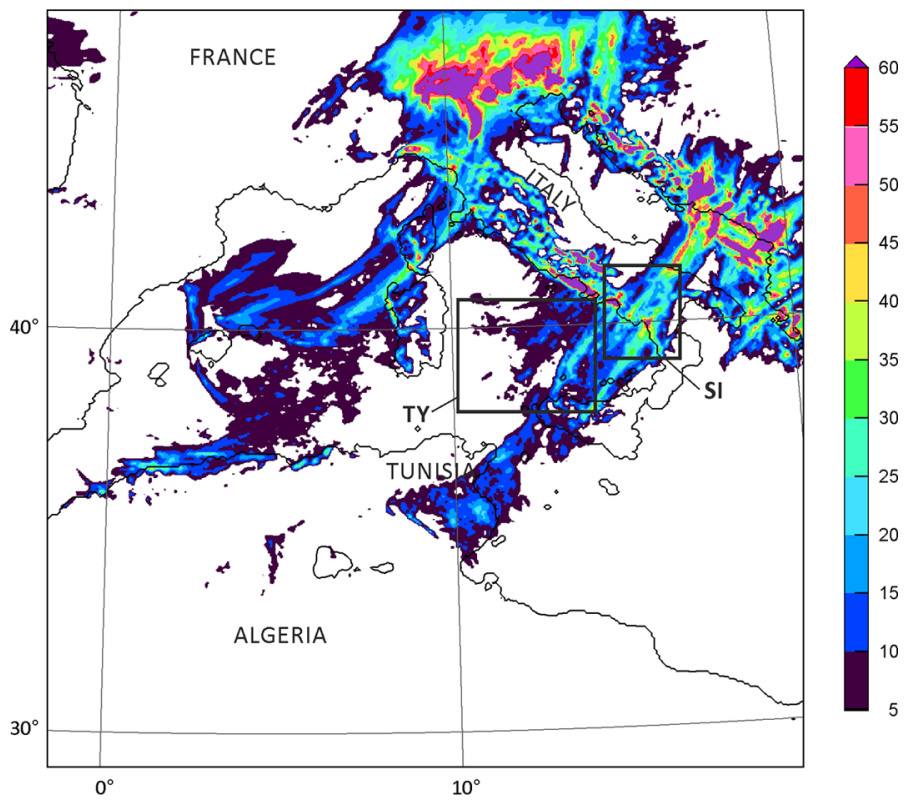

Figure 1. Accumulated precipitation during IOP 13 from 00:00 UTC on 15 October 2012 to 03:00 UTC on 16 October 2012 obtained from (a) the rain gauge network and (b) the COSMOiso simulation.

zations, the reader is referred to Doms et al. (2005) and Pfahl et al. (2012), respectively.

In this study, a horizontal grid spacing of $0.0625^{\circ}$ (in a rotated grid), corresponding to about $7 \mathrm{~km}$, is used with 40 hybrid vertical levels. The model domain covers the northwestern Mediterranean, the east Atlantic, and the northern African regions (longitude ranging from -16.3 to $22.8^{\circ} \mathrm{E}$ and latitude ranging from 17.3 to $49.2^{\circ} \mathrm{N}$, i.e. about $4300 \mathrm{~km} \times 3500 \mathrm{~km}$ ). The simulation starts at 00:00 UTC on 12 October 2012 and runs for $5 \mathrm{~d}$, producing output fields every hour. The initial and boundary conditions for the standard variables are provided by the operational analysis data from the European Centre for Medium-Range Weather Forecasts (ECMWF). For the period in October 2012, these data are interpolated to the COSMO grid, with a spectral resolution of T1279 and 91 vertical levels. The model boundaries are updated with inputs of the analysis data every $6 \mathrm{~h}$, using a relaxation scheme (Davies, 1976). For the water isotopes, initial and boundary data are taken from a historical isotope global circulation model IsoGSM (which is based on the Scripps Experimental Climate Prediction Center's Global Spectral Model (GSM) that was used operationally for medium-range forecasts at NCEP) simulation by Yoshimura et al. (2008), who performed these simulations using a nudging technique (see also Pfahl et al., 2012). The Scripps Experimental Climate Prediction Center's GSM was based on the mediumrange forecast model used at NCEP for making operational analysis and predictions.

\subsection{Trajectory calculation}

Air parcel backward trajectories (Wernli and Davies, 1997; Sprenger and Wernli, 2015) are calculated using the 3-D wind fields from the COSMOiso simulation. In total 1440 trajectories per hourly time step are started from 60 grid points within a box over SI (bounded by $15.2^{\circ} \mathrm{W}, 16.6^{\circ} \mathrm{W}$, $39.6^{\circ} \mathrm{N}, 41.3^{\circ} \mathrm{N}$; Fig. 1) and 24 different vertical levels between 1000 and $400 \mathrm{hPa}$. The trajectories are computed $5 \mathrm{~d}$ back in time. Note that generally the COSMO trajectories move out of the regional model domain after $3 \mathrm{~d}$. The air parcel position as well as the interpolated conditions $\left(\delta^{18} \mathrm{O}\right.$, water vapour mixing ratio $q$, surface evaporation) along the trajectories are written out every hour. In this study, two series of trajectories, starting at the times of the two precipitation peaks (20:00 UTC on 15 October 2012 and 00:00 UTC on 16 October 2012; lines in Fig. 2) over SI, are discussed.

\section{$2.3 q-\delta$ analysis}

As variations in $\delta$ are tied to those in specific humidity $q$, the $q-\delta$ space is often used for the interpretation of the information contained in $\delta$. The theoretical framework for understanding $q-\delta$ data is from a series of simple models that describe the mixing and condensation environments (Noone, 2012). A Rayleigh distillation model, expressed as $\delta=(\alpha-1) \ln \left(q / q_{0}\right)+\delta_{0}$, in which $\alpha$ is the coefficient of fractionation, while $q_{0}$ and $\delta_{0}$ are the humidity and the isotopic composition of the water vapour source, is used to describe the isotopic depletion of water vapour that experiences 


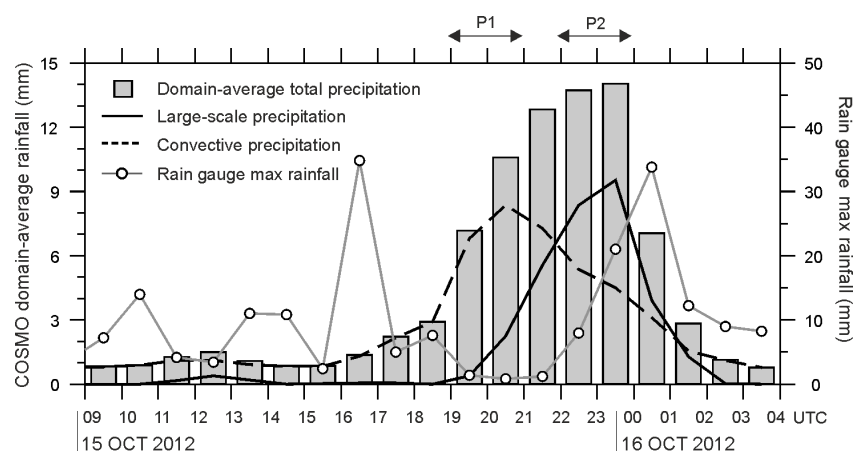

Figure 2. COSMOiso-produced domain-averaged total precipitation (bar), synoptic precipitation (black solid line), and convective precipitation (dashed line) in domain of southern Italy (SI) over the land during IOP 13. Temporal evolution of observed maximum rainfall within the SI domain is shown by a line with dot. The location of domain SI is depicted by the box in Fig. 1.

condensation and equilibrium. In this study, $q_{0}$ and $\delta_{0}$ are set to $15 \mathrm{~g} \mathrm{~kg}^{-1}$ and $-10 \%$, respectively. The mixing model is $\delta=q_{0}\left(\delta_{0}-\delta_{F}\right) 1 / q+\delta_{F}$, in which the subscript $F$ denotes the flux into the volume of interest, here set to $-12 \%$.

Mixing and distillation of water vapour with various origins can take place over a wide range of combinations and generate $q-\delta$ pairs in between the boundaries of two models. A tropical water vapour source can be used to identify the lower limit of the domain of $q-\delta$ pairs in a Rayleigh model. A mixing model, accounting for mixing between upper tropospheric depleted and dry air masses and the tropical boundary layer enriched and humid air masses, can be used to define the upper limit of the domain. The large-scale distribution of water vapour isotope ratios results from a balance between the condensation-related depleting effects (linked to Rayleigh processes), mixing of air masses with different isotopic composition during large-scale transport, and the boundary layer source effects leading to an enrichment of air masses (Noone, 2008, and Galewsky and Hurley, 2010). Also note that raindrop re-evaporation can lead to $q-\delta$ pairs below the Rayleigh distillation model (Worden et al., 2007).

\section{Overview of meteorological conditions}

\subsection{One HPE with two precipitation phases over southern Italy}

From 00:00 UTC on 15 October to 03:00 UTC on 16 October 2012, the SI area (box marked by "SI" in Fig. 1) was affected by a HPE, with two phases of precipitation. The large amount of maximum precipitation (in total $62.4 \mathrm{~mm}$ over $27 \mathrm{~h}$ ) recorded by the rain gauge network (Fig. 1a) is realistically reproduced by the COSMOiso simulation (maximum precipitation of $59 \mathrm{~mm}$; Fig. 1b), both in terms of amplitude and spatial distribution. The temporal evolution of the COS-
MOiso domain-averaged total precipitation within the SI area (bars in Fig. 2) shows precipitation in excess of $10 \mathrm{~mm}$ within the SI region between 19:00 UTC on 15 October and 01:00 UTC on 16 October. The period has two distinct precipitation phases: (1) a convective precipitation phase (P1) in the late afternoon (19:00-21:00 UTC) on 15 October (dashed line in Fig. 2) and (2) a large-scale precipitation phase (P2) just before midnight (22:00-00:00 UTC) on that day (solid line). The precipitation associated with $\mathrm{P} 1$ is delayed by $4 \mathrm{~h}$ in the COSMOiso simulation compared to the precipitation recorded by the rain gauge network, which shows a peak at 16:00-18:00 UTC (grey line with dot in Fig. 2), while the precipitation during $\mathrm{P} 2$ is closely reproduced by the simulation with a good timing $(\sim 1 \mathrm{~h}$ early, with the measured peak occurring at 23:00-01:00 UTC). P1 is related to rain from the convection parameterization, and $\mathrm{P} 2$ is related to rain associated with large-scale vertical motion. The model, in contrast to the observations, does not produce two peaks in the total precipitation. These peaks can be seen by looking at the two precipitation types separately. In the following, 20:00 UTC on 15 October and 00:00 UTC on 16 October are considered times representative of $\mathrm{P} 1$ and $\mathrm{P} 2$, respectively, while 16:00 UTC on 15 October is considered representative of the pre-HPE conditions.

\subsection{Distribution of SWI over the Mediterranean}

The moisture structure upstream of the HPE studied by Lee et al. (2016) has been further analysed. Three features are highlighted below: (1) the presence of an African moisture plume favouring the efficiency of the convection to produce more precipitation, (2) the significance of the southerly flow from the warmer Mediterranean Sea to the south of Sicily in strengthening the convergence ahead of the cold front, and (3) the role of the extended upper-level trough over southern France and the western Mediterranean in enhancing convection at the leading edge of the surface front. At 16:00 UTC on 15 October 2012, an upper-level trough, located over south-eastern France, extends to northern Algeria. Sea-level pressure values lower than $1006 \mathrm{hPa}$ can be observed over south-eastern France extending to northern Italy (Fig. 3a), with the associated cyclonic flow seen at $850 \mathrm{hPa}$. Strong northerly mistral and tramontane winds associated with cold and dry air with $\delta^{18} \mathrm{O}_{\mathrm{v}}$ less than $-16 \%$ and $q$ less than $2 \mathrm{~g} \mathrm{~kg}^{-1}$ (Fig. 4a, b) and low potential temperature $\theta$ are located over the Gulf of Lion $(\leq 300 \mathrm{~K}$, dark blue area in Fig. 3b). Figure 4a shows two bands of large $q$ values in excess of $6 \mathrm{~g} \mathrm{~kg}^{-1}$ at $850 \mathrm{hPa}$ upstream of the HPE, one over the Tyrrhenian Sea ("TY" box in Fig. 3b), where a cold front is located (large gradient of $\theta$ in range of $315-330 \mathrm{~K}$, dashed line in Fig. 3b), and another one across north Africa extending towards SI with south to south-westerly winds, where the African moisture plume with values of $\theta \geq 330 \mathrm{~K}$ is located ahead of the trough (red area in Fig. 3b). At $600 \mathrm{hPa}$ (Fig. $4 \mathrm{c}), \delta^{18} \mathrm{O}_{\mathrm{v}}$ in excess of $-25 \%$ o can be seen at the south- 
(a) Surface pressure and $500 \mathrm{hPa}$ geopotential height

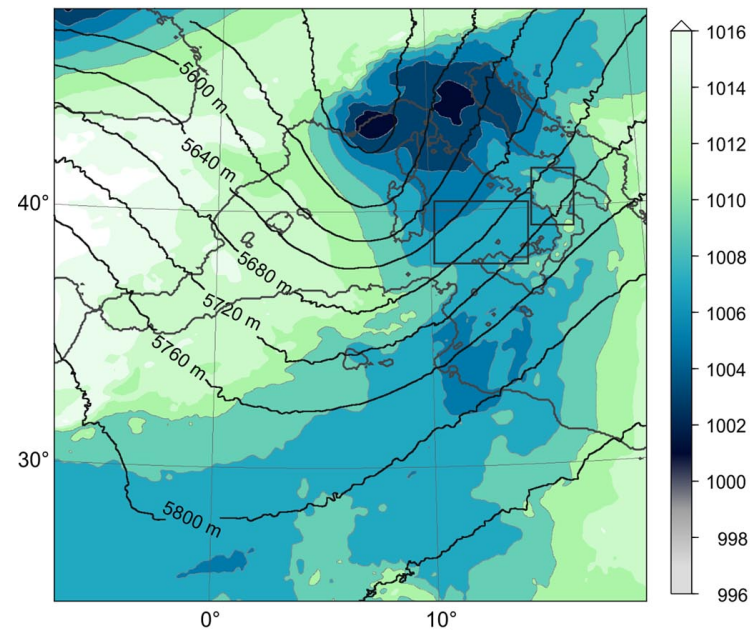

(c) Surface pressure and $500 \mathrm{hPa}$ geopotential height

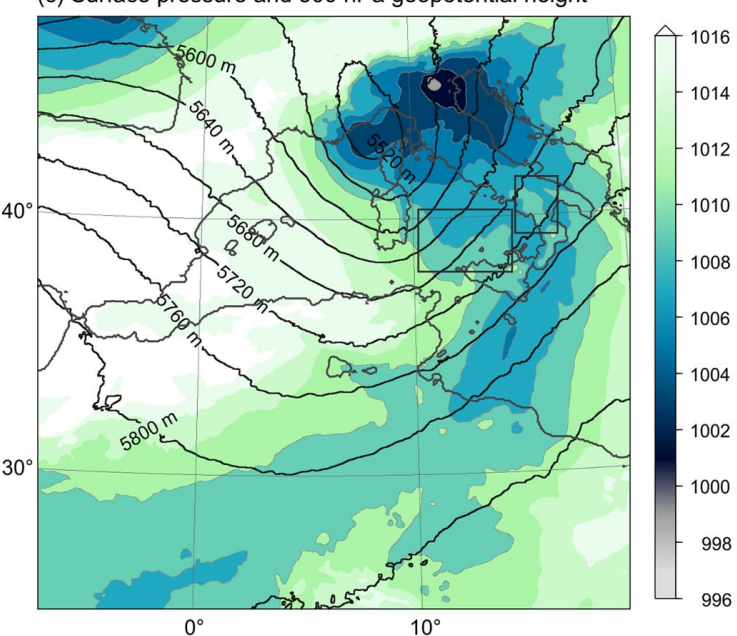

(e) Surface pressure and $500 \mathrm{hPa}$ geopotential height

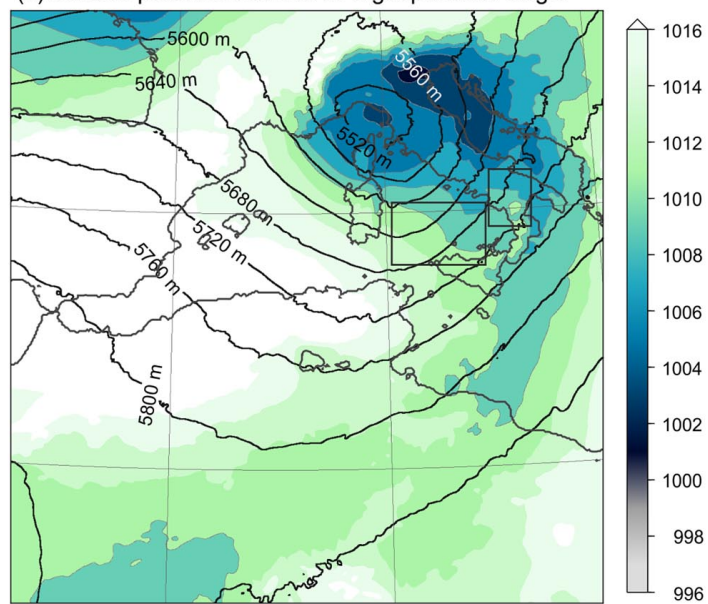

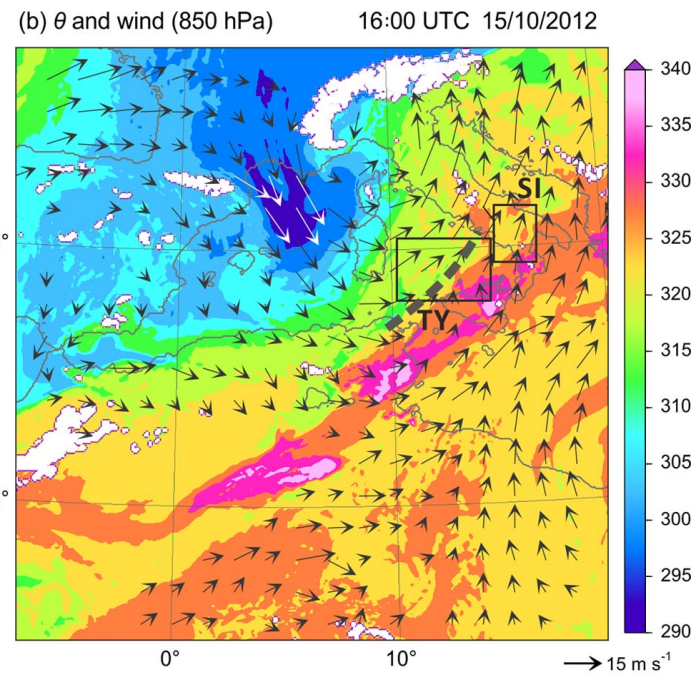

(d) $\theta$ and wind $(850 \mathrm{hPa}) \quad 20: 00$ UTC $15 / 10 / 2012$
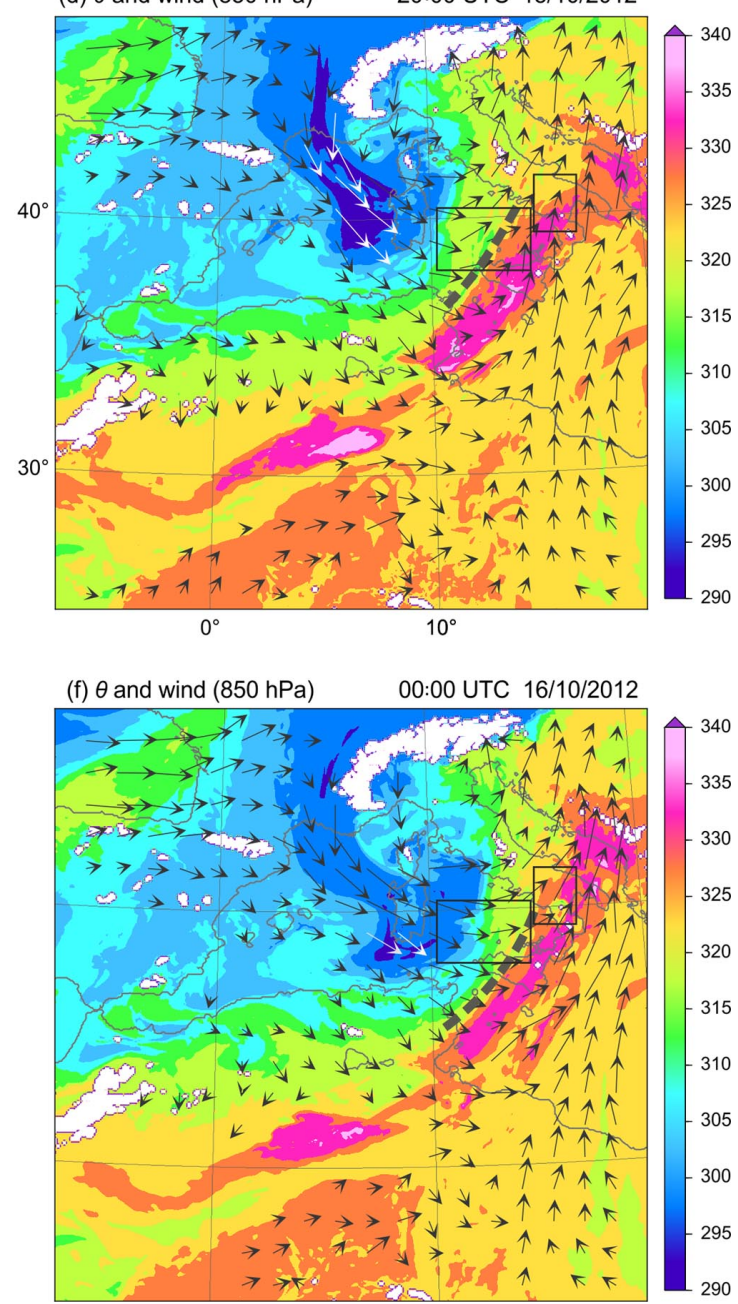

Figure 3. Horizontal distributions of sea-level pressure (shades) and geopotential height at $500 \mathrm{hPa}$ (contour) (a, c, e) and potential temperature, $\theta$ (shades), and wind (black and white arrows) at $850 \mathrm{hPa}(\mathbf{b}, \mathbf{d}, \mathbf{f})$ at 16:00 UTC (a, b) and at 20:00 UTC (c, d) on 15 October 2012 and at 00:00 UTC on 16 October 2012 (e, f) produced by the COSMOiso simulation. The coastline is depicted by the black line. The location of the cold front is depicted by a dashed line in panels $(\mathbf{b}, \mathbf{d}$, and $\mathbf{f})$. 
ern edge of the surface cold front. This signature can be explained by the transport of water vapour to higher levels by updrafts along the front. Comparing the maps of $q$ and $\delta^{18} \mathrm{O}_{\mathrm{v}}$ (crescent closed by a dashed line in Fig. $4 \mathrm{a}-\mathrm{b}$ ) reveals an additional band of enriched water vapour $\left(\delta^{18} \mathrm{O}_{\mathrm{v}} \geq-18 \%\right.$; Fig. 4b) is found at the southern boundary of the mistral (and the tramontane), in a region of still relatively low $q$ $\left(\leq 5 \mathrm{~g} \mathrm{~kg}^{-1}\right.$; Fig. 4a). This SWI-enriched band reflects the moisture brought to higher levels by convective updrafts that develop within the strong mistral outflow over the warm sea surface, typical of cold-air outbreaks. In this region, a band of moderate brightness temperature at $10.8 \mu \mathrm{m}(230-240 \mathrm{~K}$, altitudes about $5-6 \mathrm{~km}$ ) is measured by the Spinning Enhanced Visible and Infrared Imager on board the geostationary Meteosat Second Generation satellite (not shown; see Fig. 4 of Lee et al., 2016). In the simulation, weak precipitation is also produced in this region from clouds located mostly below $5 \mathrm{~km}$ above sea level (a.s.l.) (not shown).

The hourly evolution of the moist and SWI-enriched air mass over the TY during the period 16:00-20:00 UTC can also be seen in Fig. 5, which shows the average $\delta^{18} \mathrm{O}_{\mathrm{v}}$ in $1 \mathrm{~km}$ deep layers spanning from 1 to $7 \mathrm{~km}$ a.s.l. in the TY region from 09:00 UTC on 15 October to 09:00 UTC on 16 October together with the average $\theta$ values at $850 \mathrm{hPa}$ within TY. From 09:00 to 19:00 UTC on 15 October, while the average $\theta$ at $850 \mathrm{hPa}$ is consistently high at $322 \mathrm{~K}, \delta^{18} \mathrm{O}_{\mathrm{v}}$ between 1 and $5 \mathrm{~km}$ a.s.l. increases slightly, but $\delta^{18} \mathrm{O}_{\mathrm{v}}$ between 5 and $7 \mathrm{~km}$ a.s.l. gradually decreases, revealing the arrival of the upper-level trough (Fig. 5a).

At 20:00 UTC (Fig. 3c, d), southerly winds (10-15 $\mathrm{m} \mathrm{s}^{-1}$ ) transport the warm and moist air mass with high $\theta(\geq 325 \mathrm{~K})$ from the Strait of Sicily to SI, and the convection occurred in the high $\theta$ region at the southern edge of the front (dashed line in Fig. 3d). The frontal wind convergence of southwesterly and southerly winds $\left(10-15 \mathrm{~m} \mathrm{~s}^{-1}\right)$ can be seen upstream of the HPE at $850 \mathrm{hPa}$. Meanwhile, the African moisture plume including the SWI-enriched air mass $(q \geq$ $10 \mathrm{~g} \mathrm{~kg}^{-1}$ and $\delta^{18} \mathrm{O}_{\mathrm{v}} \geq-16 \%$ in Fig. $4 \mathrm{~d}-\mathrm{f}$ ) continues to advect toward SI.

At 00:00 UTC, when the trough is located in the southern Tyrrhenian Sea with the low-level mistral air mass ( $q \leq$ $3 \mathrm{~g} \mathrm{~kg}^{-1}$ and $\delta^{18} \mathrm{O}_{\mathrm{v}} \leq-24 \%$ in Fig. $4 \mathrm{~g}-\mathrm{h}$ ), strong cyclonic flow can be identified over the SI region, while the warm and moist air mass $(\theta \geq 325 \mathrm{~K})$ over the Strait of Sicily is continuously advected towards SI (Fig. 3f). Higher up, at $600 \mathrm{hPa}$, the trough-related, strongly SWI-depleted air masses descending from higher altitudes show $\delta^{18} \mathrm{O}_{\mathrm{v}}$ lower than $-45 \%$ o (Fig. 4i). In contrast to the trough, the African moisture plume is associated with large $q$ in excess of $10 \mathrm{~g} \mathrm{~kg}^{-1}$ at the $850 \mathrm{hPa}$ level extending to the SI region (Fig. 4g).

During the two precipitation phases at 20:00 and 00:00 UTC, both $\theta$ and $\delta^{18} \mathrm{O}_{\mathrm{v}}$ drop dramatically in the TY region with arrival of the upper-level trough and cold front (Fig. 5a), while the warm and moist air mass with large $q$ and large $\delta^{18} \mathrm{O}_{\mathrm{v}}$ coming from tropical Africa persists upstream of SI (Fig. 5b). As $\theta$ decreases from 322 to $300 \mathrm{~K}$ in TY (Fig. 5a), the $\delta^{18} \mathrm{O}_{\mathrm{v}}$ drops more rapidly at altitudes above $3 \mathrm{~km}$ compared to the $\delta^{18} \mathrm{O}_{\mathrm{v}}$ drop seen in lower altitudes, where the trough-related dry airstreams are moistened by SWI-enriched fresh ocean evaporate. The minimum $\delta^{18} \mathrm{O}_{\mathrm{v}}$ increases the lower the altitudes are to the near surface; for instance, minimum $\delta^{18} \mathrm{O}_{\mathrm{v}}$ values of $-23 \%$ and $-36 \%$ o are seen at $1-2$ and $2-3 \mathrm{~km}$ a.s.l. respectively, while values lower than $-47 \%$ occur at altitudes above $3 \mathrm{~km}$ a.s.l. The hourly evolution of average $\delta^{18} \mathrm{O}_{\mathrm{v}}$ in the TY region shows the propagation of the surface front and upper-level trough at altitudes of 1-7 km a.s.l. and the associated subsidence of dry and cold air. It is worth noting that the arrival timing of cold and dry air subsidence in TY, 19:00-20:00 UTC (Fig. 5a), corresponds to the onset of precipitation in SI at 19:00 UTC (vertical bars, Fig. 2). Overall the synoptic evolution simulated by COSMOiso is similar to the one analysed using an observational dataset by Lee et al. (2016).

\section{SWI distribution during the two precipitation phases}

The temporal evolution of the domain-averaged $\delta^{18} \mathrm{O}_{\mathrm{v}}$ in water vapour and $q$ within the SI area at the first model level (approximately $20 \mathrm{~m}$ a.s.l.) (Fig. 6) shows the different behaviour during IOP 13 . While $q$ increases gradually to $13.5 \mathrm{~g} \mathrm{~kg}^{-1}$ until 19:00 UTC, just before $\mathrm{P} 1, \delta^{18} \mathrm{O}_{\mathrm{v}}$ maximizes to $-13.6 \%$ at $16: 00$ UTC and then decreases during $\mathrm{P} 1$ to $-15 \%$. During $\mathrm{P} 2, \delta^{18} \mathrm{O}_{\mathrm{v}}$ increases shortly to $-14.6 \%$, whereas $q$ continues to decrease to $8 \mathrm{~g} \mathrm{~kg}^{-1}$. The detailed 3-D history and structure of $\delta^{18} \mathrm{O}$ and $q$ of the air parcels associated with P1 and P2 over SI will be shown in the following section.

\subsection{Phase 1: the convective phase}

\subsubsection{History of air parcels and related SWI evolution}

This section aims to investigate the history of the air masses involved in the convective precipitation phase P1. Figure 7 displays the history of the air parcel arriving at SI in the layer $800-700 \mathrm{hPa}$ at 20:00 UTC on 15 October 2012 . The $3 \mathrm{~d}$ backward trajectories in Fig. 7 indicate that the air parcels arriving at SI in the $800-700 \mathrm{hPa}$ layer originated over the North Atlantic. These air parcels remain dry $\left(q \leq 5 \mathrm{~g} \mathrm{~kg}^{-1}\right)$ along the track during the $3 \mathrm{~d}$ except for the last $18 \mathrm{~h}$ before their arrival in SI (Fig. 7a). In the period between 48 and $18 \mathrm{~h}$ before their arrival in SI, the air parcels descend from altitudes of 3-5 km to below $1 \mathrm{~km}$ a.s.l. over the Tyrrhenian Sea and below $2.5 \mathrm{~km}$ a.s.l. over the Strait of Sicily (Fig. 7d). This penetration of dry air from upper levels to the surface enhances surface evaporation, leading to a sharp increase of $q$ and $\delta^{18} \mathrm{O}_{\mathrm{v}}$ (Fig. 7a-c). When the air parcels travel over the sea, e.g. during $24-18 \mathrm{~h}$, or $18-6 \mathrm{~h}$ before their arrival in SI, the surface evaporation instantly increases. For instance, 
16:00 UTC 15/10/2012

(a) Water vapour mixing ratio $\left(\mathrm{g} \mathrm{kg}^{-1}\right) \quad 850 \mathrm{hPa}$
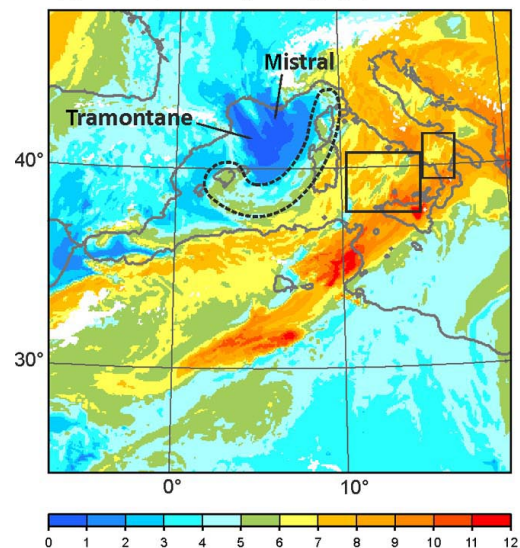

20:00 UTC 15/10/2012

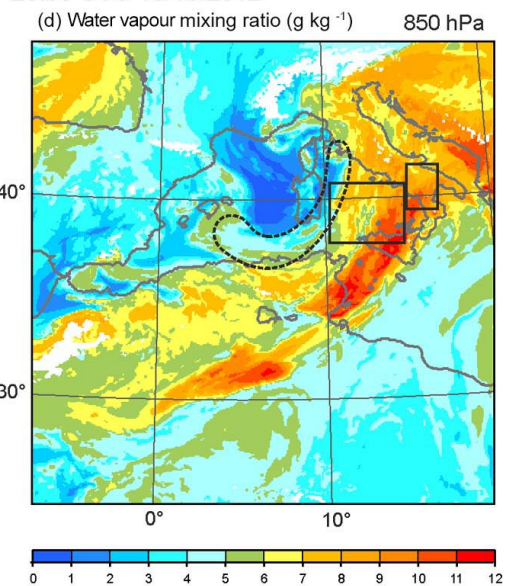

00:00 UTC 16/10/2012

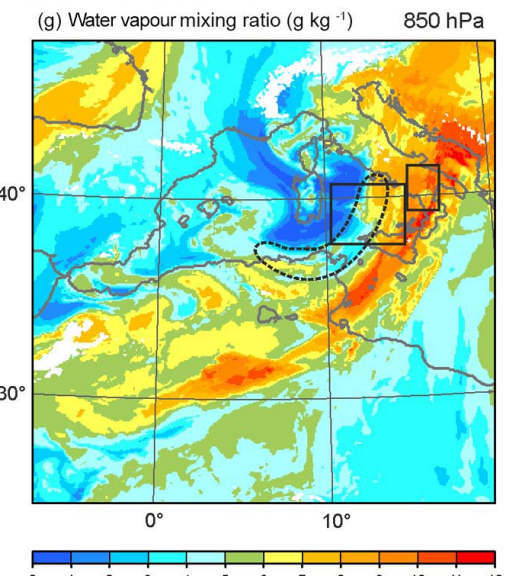

(b) $\delta 180,(\%)$
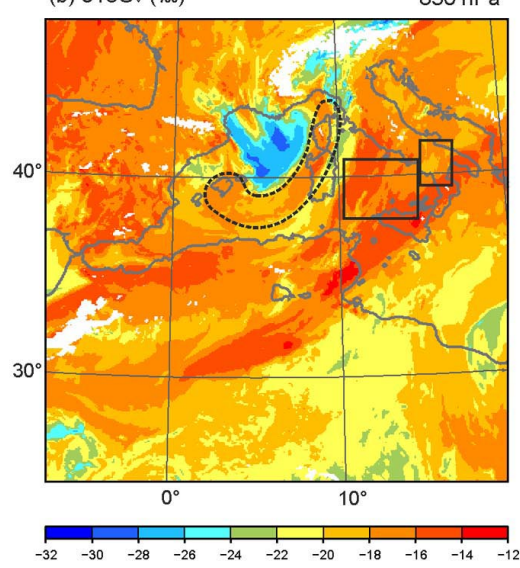

(e) $\delta 180 v(\%)$

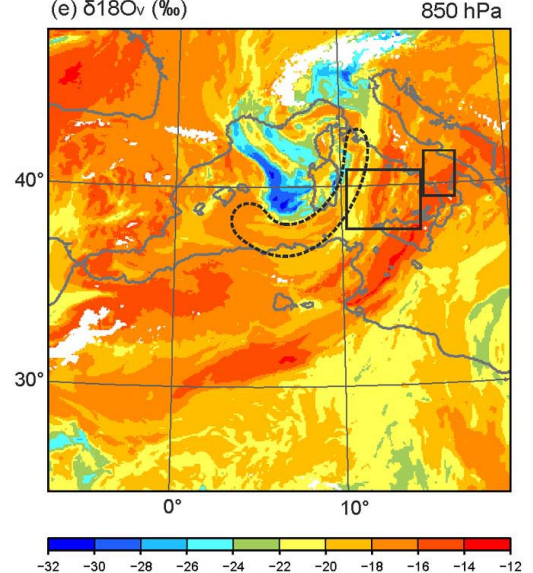

(h) $\delta 180 \mathrm{~V}(\%)$

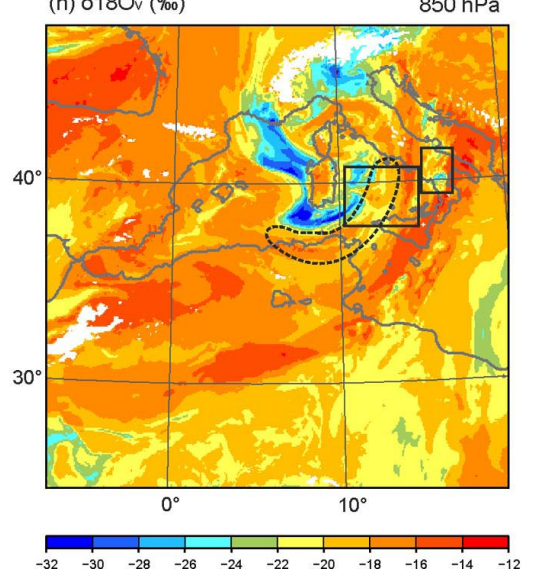

(c) $\delta 180 v(\%)$
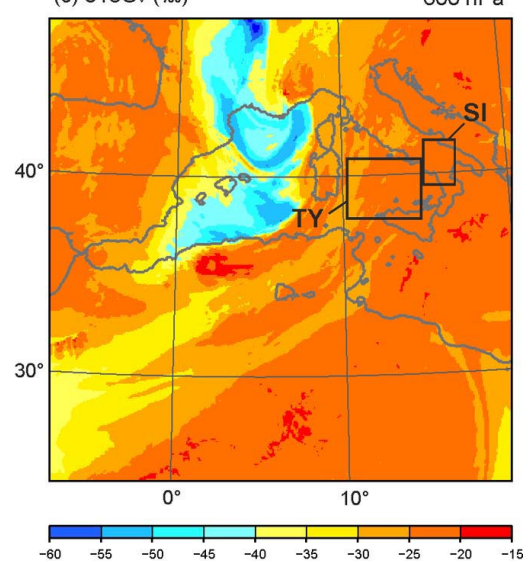

(f) $\bar{\delta} 180 \mathrm{v}(\%)$

$600 \mathrm{hPa}$

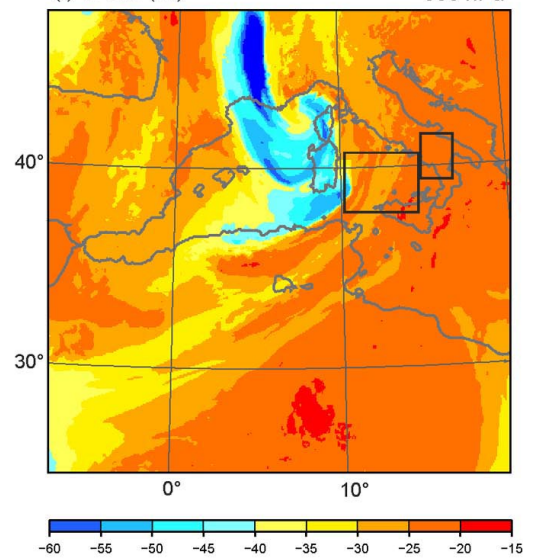

(i) $\delta 180 v(\%)$

$600 \mathrm{hPa}$

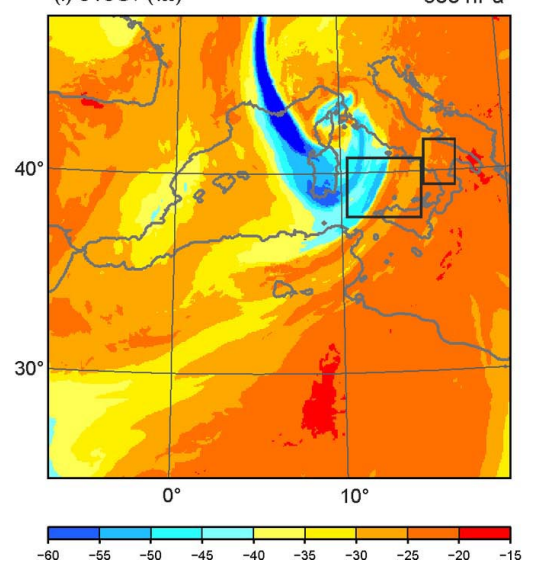

Figure 4. Horizontal distributions of water vapour mixing ratio at $850 \mathrm{hPa}(\mathbf{a}, \mathbf{d}, \mathbf{g}), \delta^{18} \mathrm{O}_{\mathrm{v}}$ at $850 \mathrm{hPa}(\mathbf{b}, \mathbf{e}, \mathbf{h})$, and $\delta^{18} \mathrm{O}_{\mathrm{v}}$ at $600 \mathrm{hPa}(\mathbf{c}, \mathbf{f}, \mathbf{i})$ at 16:00 UTC (a-c) and 20:00 UTC (d-f) on 15 October 2012 and at 00:00 UTC on 16 October 2012 (g, h, i).

between 18 and $6 \mathrm{~h}$ before arrival in SI, the median surface evaporation rate along the trajectories doubles from 0.15 to $0.32 \mathrm{~mm} \mathrm{~h}^{-1}$, with a peak $12 \mathrm{~h}$ before the arrival in SI. A few air parcels travel over the Strait of Sicily towards SI, where they mix with the moist and SWI-enriched moisture plume from north Africa (Fig. 4d-f). The median of $q$ along the trajectories increases by a factor of 2.5 from 3.8 to $8.4 \mathrm{~g} \mathrm{~kg}^{-1}$, with the peak $10 \mathrm{~h}$ before arrival in SI, whereas the median $\delta^{18} \mathrm{O}_{\mathrm{v}}$ value increases from $-27 \%$ o to $-18 \%$ (not shown). 
(a) Tyrrhenian Sea

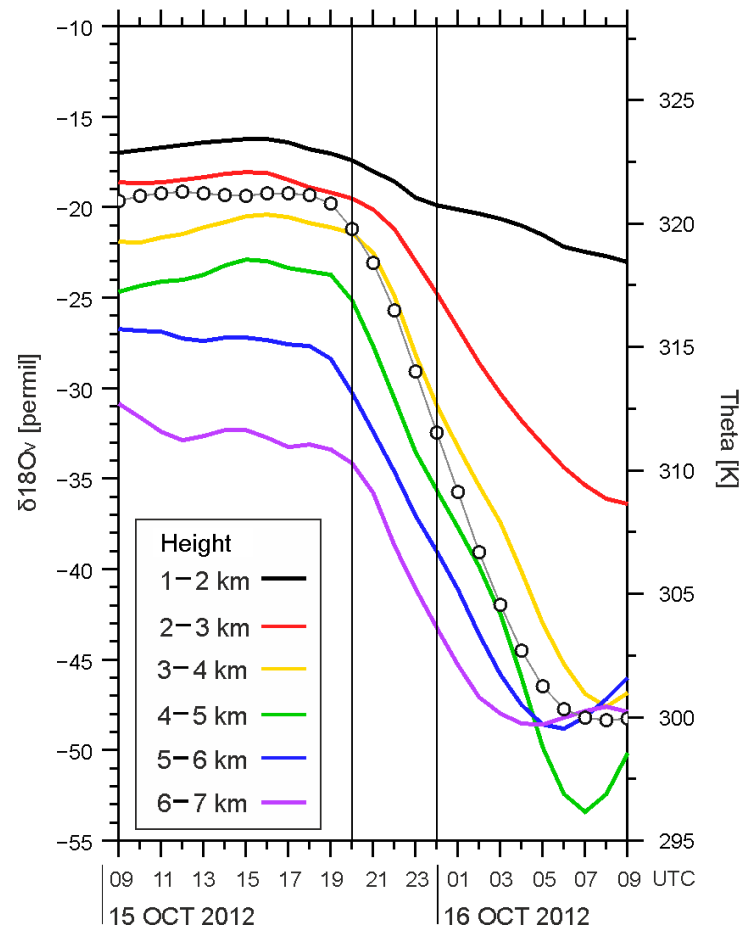

(b) Southern Italy

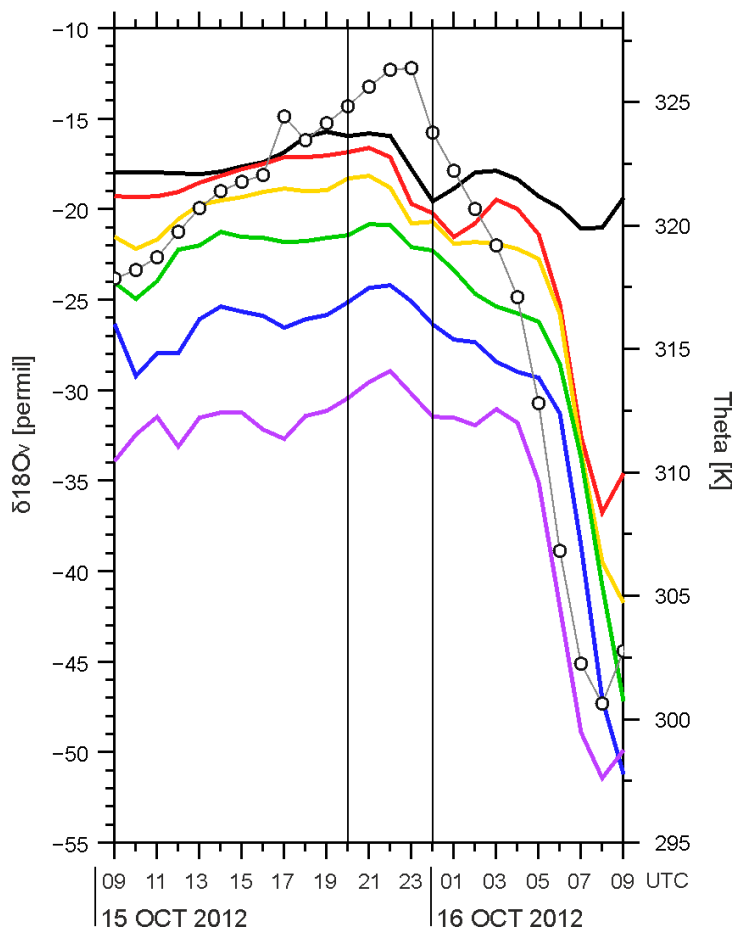

Figure 5. The averaged values of potential temperature $(\theta, \mathrm{K})$ at $850 \mathrm{hPa}$ (thin line with dot) and $\delta^{18} \mathrm{O}_{\mathrm{v}}(\%$ o ) at altitudes of $1-2 \mathrm{~km}$ a.s.l. (black), 2-3 km a.s.l. (red), 3-4 km a.s.1. (yellow), 4-5 km a.s.l. (green), 5-6 km a.s.l. (blue), and 6-7 km a.s.1. (purple) over the sea surface upstream of the HPE of IOP 13 within domains of (a) the Tyrrhenian Sea (marked by "TY" in Figs. 1, 3, and 4) and (b) southern Italy (marked by "SI") from 09:00 UTC on 15 October 2012 to 09:00 UTC on 16 October 2012.

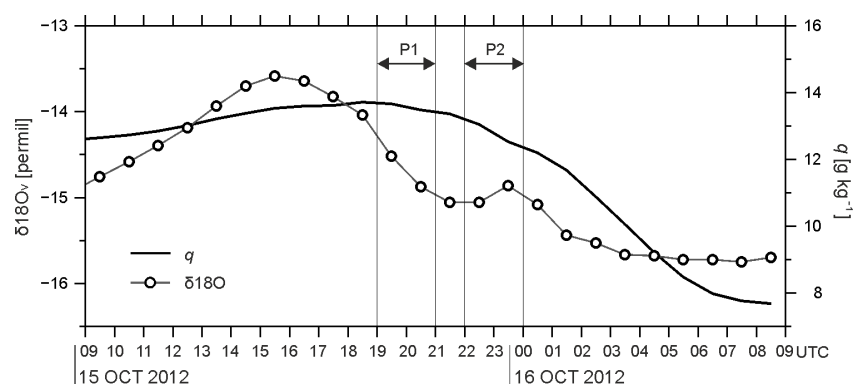

Figure 6. Domain-averaged $\delta^{18} \mathrm{O}_{\mathrm{v}}$ (line with dot) and $q$ (thick line) in the domain of southern Italy (SI) at the first model level (approximately $20 \mathrm{~m}$ height) (limited to the grid point where the topography is lower than $20 \mathrm{~m}$ ), from 09:00 UTC on 15 October 2012 to 09:00 UTC on 16 October 2012. The location of the domain SI is depicted by the box in Figs. 1, 3, and 4.

Figure 8 displays the $q-\delta^{18} \mathrm{O}_{\mathrm{v}}$ scatter diagram along the entire trajectories seen in Fig. 7 at different times before their arrival, showing that $q$ and $\delta^{18} \mathrm{O}_{\mathrm{v}}$ increase rapidly in the last $12 \mathrm{~h}$ before the parcels arrive over SI. Between 60 and $12 \mathrm{~h}$ before their arrival (Fig. 8a, b), $q$ and $\delta^{18} \mathrm{O}_{\mathrm{v}}$ are still relatively small, at around $2-6 \mathrm{~g} \mathrm{~kg}^{-1}$ and between $-25 \%$ o and $-19 \%$, respectively. During the last $12 \mathrm{~h}$ (black star, Fig. $8 \mathrm{~b}), q$ is about $9 \mathrm{~g} \mathrm{~kg}^{-1}$ on average, and the average $\delta^{18} \mathrm{O}_{\mathrm{v}}$ is about $-17 \%$ o. During this time, the $q-\delta^{18} \mathrm{O}_{\mathrm{v}}$ evolution follows a curve that lies close to a typical Rayleigh line for conditions in the Mediterranean (sea surface temperature of $26^{\circ} \mathrm{C}$, dashed line), indicating the onset of precipitation. Several points fall substantially below this Rayleigh distillation line (solid line, Fig. 8b), suggesting a precipitation recycling by partial re-evaporation of raindrops (Worden et al., 2007).

Between 6 and $3 \mathrm{~h}$ before their arrival in SI, the upperto low-level trajectories (green to purple dots in Fig. 9a, b) follow a mixing line (dashed line) during their descent, while the lowermost trajectories (black and grey dots) are distributed over a wider domain and do not follow a Rayleigh distillation line exactly (solid line). This shows that the descending dry air parcels mix with the warm and moist air parcels from lower altitudes, which also increases surface evaporation. During P1 (Fig. 9c), the $q-\delta^{18} \mathrm{O}_{\mathrm{v}}$ evolution at all levels lies on and below the Rayleigh line, suggesting that air parcels are representative of the convective updraft after condensation of the raindrops $\left(q-\delta^{18} \mathrm{O}_{\mathrm{v}}\right.$ along the Rayleigh curve) and that some air parcels took up the evaporated moisture from falling precipitation. 

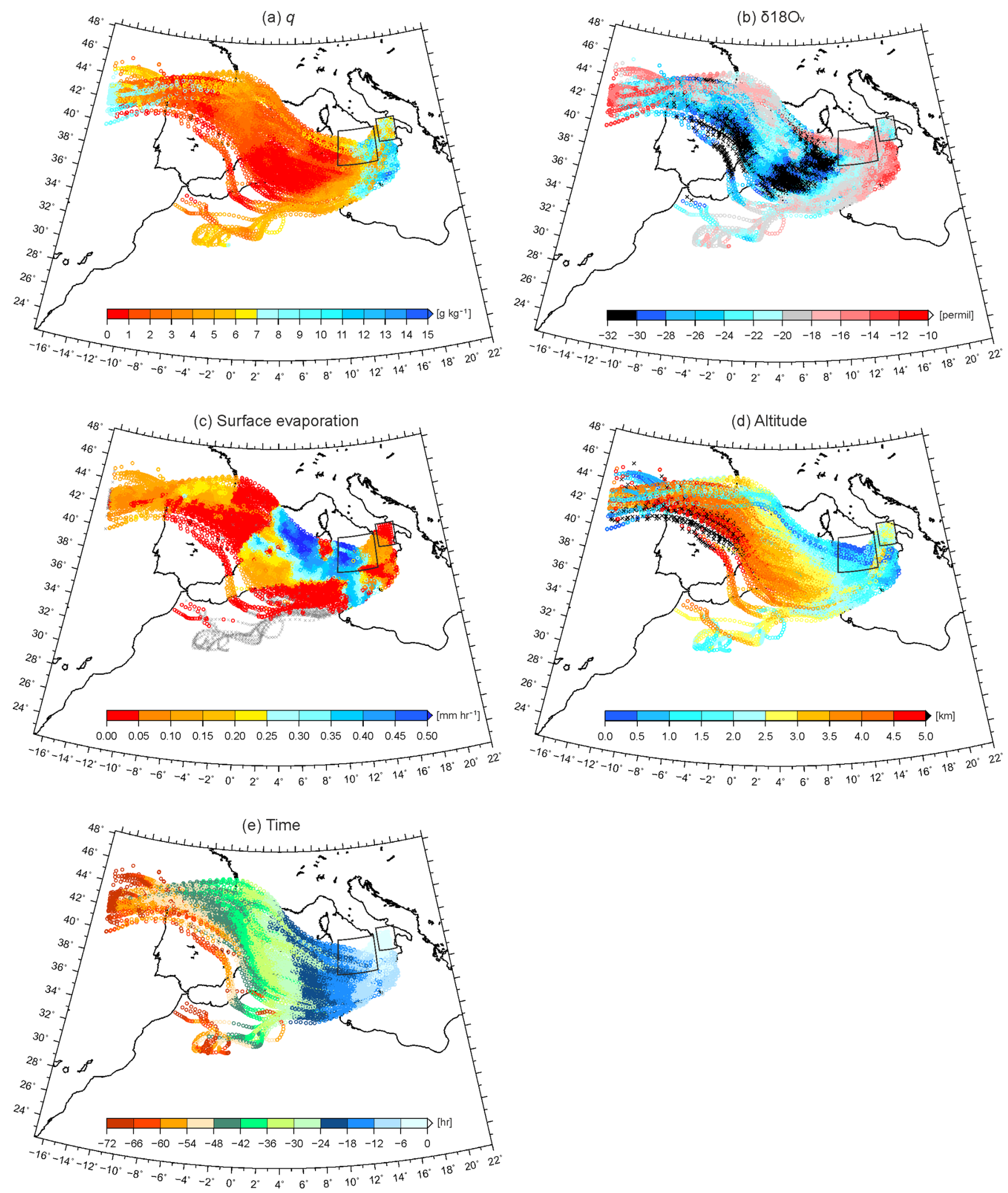

Figure 7. History of air parcel arriving at SI in the 800-700 hPa layer at 20:00 UTC on 15 October 2012. (a) Water vapour mixing ratio, $q$ $\left(\mathrm{g} \mathrm{kg}^{-1}\right)$, (b) $\delta^{18} \mathrm{O}_{\mathrm{v}}(\% o)$, (c) surface evaporation $\left(\mathrm{mm} \mathrm{h}^{-1}\right)$, (d) altitude $(\mathrm{km})$, and (e) time (h). 


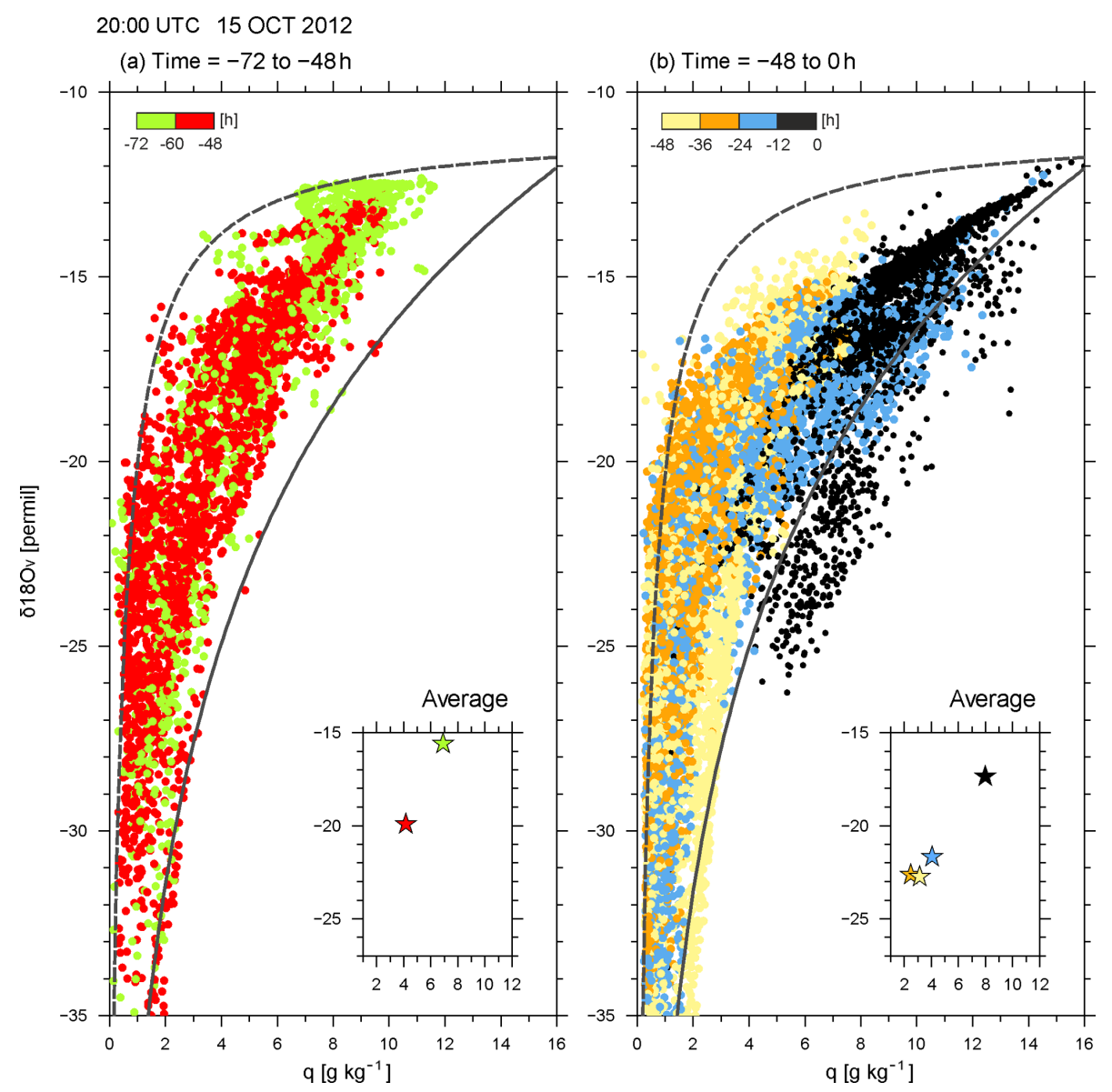

Figure 8. Scatter diagram of $q$ and $\delta^{18} \mathrm{O}_{\mathrm{v}}$ along the backward trajectories of Fig. 7 during (a) the times between -72 and $-48 \mathrm{~h}$ and (b) times between -48 and $0 \mathrm{~h}$ every $12 \mathrm{~h}$ from 20:00 UTC on 15 October 2012. The colour of dots changes every $12 \mathrm{~h}$. The mixing and Rayleigh lines are indicated in each panel by dashed and solid lines, respectively. The averaged $q$ and $\delta^{18} \mathrm{O}_{\mathrm{v}}$ every $12 \mathrm{~h}$ are displayed in the bottom right corner of each panel.

\subsubsection{Horizontal SWI distribution}

At 20:00 UTC, the precipitation over SI is associated with a convective line, which extends from SI to the Strait of Sicily (area closed by dashed line in Fig. 10a) and is located ahead of the surface cold front. Westerly and north-westerly winds prevail at $542 \mathrm{~m}$ a.s.l. (Fig. 10b), while south-westerly wind is dominant at $2455 \mathrm{~m}$ a.s.l. (Fig. 10d). Within the precipitation area, lower $\delta^{18} \mathrm{O}_{\mathrm{v}}$ values $(\leq-16 \%$ o) than in the vicinity are found at $542 \mathrm{~m}$ a.s.l., while locally higher $\delta^{18} \mathrm{O}_{\mathrm{v}}$ values are found at 2455 and $5565 \mathrm{~m}$ a.s.l. (Fig. 10d, f), indicating the presence of strong and deep convective mixing. This convection causes the vertical transport of SWI-depleted moisture towards the surface within the downdrafts, and SWIenriched moisture is pumped to higher altitudes within the updrafts. This signature is consistent with the temporal evolution of average $\delta^{18} \mathrm{O}_{\mathrm{v}}$ in SI. Figure $5 \mathrm{~b}$ shows a larger $\delta^{18} \mathrm{O}_{\mathrm{v}}$ increase at high altitudes of 4-7 kma.s.l. (green to purple lines in Fig. 5b) than at lower altitudes of $1-3 \mathrm{~km}$ a.s.l. (black to yellow lines) from 19:00 to 22:00 UTC. The SWI-enriched air masses with high $\delta^{18} \mathrm{O}_{\mathrm{r}}$ in rain $(\geq-10 \%$ ) are distributed over the TY region (Fig. 10e), and SWI-enriched air masses with high $\delta^{18} \mathrm{O}_{\mathrm{s}}$ in snow $(\geq-16 \%$ ) are aligned ahead of the cold front over Sicily (Fig. 10g). The depletion of water vapour and the enrichment of rain water and snow over the TY indicate the uptake by the air mass of evaporated moisture from falling hydrometeors.

At the same time, the African moisture plume is associated with SWI-enriched vapour with $\delta^{18} \mathrm{O}_{\mathrm{v}}$ in excess of $-22 \%$ and SWI-enriched snow with $\delta^{18} \mathrm{O}_{\mathrm{s}}$ larger than $-12 \%$ around the southern tip of the precipitating area at $5565 \mathrm{~m}$ (Fig. 10f, g), indicating the continuous supply of the enriched moisture plume from north Africa to SI. We can see these constantly large $\delta^{18} \mathrm{O}_{\mathrm{v}}$ values in SI at all altitudes between 1 and $7 \mathrm{~km}$ during IOP13 in Fig. 5b. The dry pocket of the upper-level trough is distinguished by SWI-depleted vapour air masses with low $\delta^{18} \mathrm{O}_{\mathrm{v}} \leq-36 \%$ at 2455 and $5565 \mathrm{~m}$ a.s.l. over Sardinia and Corsica (Fig. 10d, f).

The Lagrangian analysis indicates that most processes inducing precipitation during P1 take place during the last $18 \mathrm{~h}$ 

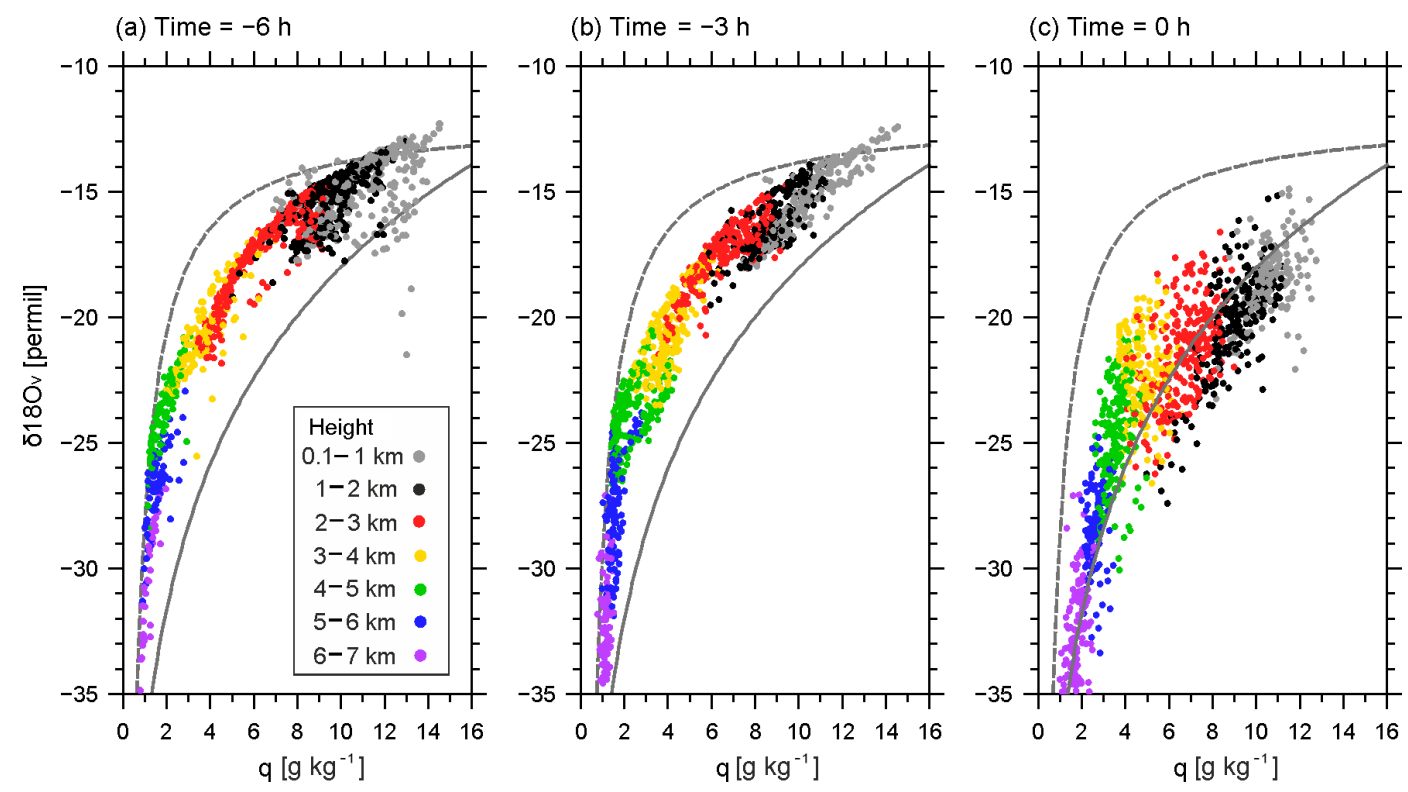

Figure 9. Scatter diagram of $q$ and $\delta^{18} \mathrm{O}_{\mathrm{v}}$ along the backward trajectories of Fig. 7 but for all altitudes of 1-2 km (black dots), 2-3 km (red dots), 3-4 km (yellow dots), 4-5 km (green dots), 5-6 km (blue dots), and 6-7 km (purple dots) at (a) $-6 \mathrm{~h}$, (b) $-3 \mathrm{~h}$, and (c) $0 \mathrm{~h} \mathrm{from}$ 20:00 UTC on 15 October 2012. The mixing and Rayleigh lines are indicated in each panel by dashed and solid lines, respectively.

over the Tyrrhenian Sea and the Strait of Sicily. The descending air parcels from the middle troposphere reach altitudes below $1 \mathrm{~km}$ a.s.l. along the cold front and take up large amounts of evaporated moisture near the warm sea surface of the Tyrrhenian Sea. Additional moisture is then taken up at altitudes below $2 \mathrm{~km}$ a.s.l. from mixing with the African moisture plume that extends from the African continent to the Strait of Sicily. During the period from 18 to $6 \mathrm{~h}$ before the precipitation peak P1, $q$ and $\delta^{18} \mathrm{O}_{\mathrm{v}}$ increase strongly. At the time of precipitation, strong convective mixing injects SWI-enriched moisture into higher altitudes and depleted moisture to near surface over SI.

\subsection{Phase 2: the large-scale phase}

\subsubsection{History of air parcel and related SWI evolution}

The $3 \mathrm{~d}$ backward trajectories in Fig. 11 evidence that the air parcels arriving at SI in the layer between 800 and $700 \mathrm{hPa}$ at 00:00 UTC on 16 October come from north Africa and partly from the southern Iberian Plateau. The air parcels are consistently moist along the tracks (Fig. 11a), with average $q$ values mostly $\geq 5 \mathrm{~g} \mathrm{~kg}^{-1}$ along the track, in contrast to the air parcels involved in P1 (see Sect. 4.1.1). During the $3 \mathrm{~d}$ prior to their arrival in SI, the air parcels are enriched with SWI, showing large $\delta^{18} \mathrm{O}_{\mathrm{v}}$ in excess of $-24 \%$, and the air parcels are located at low altitudes, mostly below $2 \mathrm{~km}$ a.s.l. (Fig. 11b, d). They continuously take up water vapour in the Strait of Sicily (Fig. 11a-b). The median of $q$ increases from 6.5 to $9 \mathrm{~g} \mathrm{~kg}^{-1}$, and the median $\delta^{18} \mathrm{O}_{\mathrm{v}}$ increases from $-18 \%$ o to $-16 \%$ in the period from 72 to $10 \mathrm{~h}$ before the onset of precipitation. The air parcels arriving at SI at 00:00 UTC at higher levels between 700 and $500 \mathrm{hPa}$ are also moist and SWI-enriched and originate from north Africa (not shown).

These moist and SWI-enriched air parcels are also evident from the scatter diagram of $q$ and $\delta^{18} \mathrm{O}_{\mathrm{v}}$. Figure 12 shows the relatively large $q$ and $\delta^{18} \mathrm{O}_{\mathrm{v}}$ values during the $3 \mathrm{~d}$ prior to their arrival in SI, i.e. $q$ of $5-16 \mathrm{~g} \mathrm{~kg}^{-1}$ (average of $8-$ $10 \mathrm{~g} \mathrm{~kg}^{-1}$ ) and $\delta^{18} \mathrm{O}_{\mathrm{v}}$ between $-12 \% 0$ and $-25 \%$ (average between $-16 \%$ and $-18 \%$ ). During this period, the minimum $\delta^{18} \mathrm{O}_{\mathrm{v}}$ of the air parcels gradually increases from $-33 \%$ to $-27 \%$. In particular, the moist branch of this $q-$ $\delta^{18} \mathrm{O}_{\mathrm{v}}$ distribution lies close to Rayleigh distillation curve (solid line, Fig. 12a-c) for all three days, indicating sustained cloud and precipitation formation. As above, values below this Rayleigh curve point to the importance of precipitation recycling, which also occurs repeatedly during the $3 \mathrm{~d}$ period.

\subsubsection{Horizontal SWI distribution}

At 00:00 UTC on 16 October during P2, stronger precipitation than that of $\mathrm{P} 1$ is produced, and the precipitation system is located mainly over SI (marked area closed by dashed line in Fig. 13a). In the vicinity of the precipitating region, strong cyclonic south-westerly flow $\geq 25 \mathrm{~m} \mathrm{~s}^{-1}$ is dominant at 2455 and $5565 \mathrm{~m}$ a.s.l. (Fig. 13d, f). Within the precipitating area, water vapour is gradually depleted, and $\delta^{18} \mathrm{O}_{\mathrm{v}}$ values are relatively low from near the surface (between $-22 \%$ o and $-26 \%$ o, $542 \mathrm{~m}$ a.s.l.) to middle altitudes of $5565 \mathrm{~m}$ a.s.l. (between $-30 \%$ and $-36 \%$ ) (Fig. 13b, d, and f). A strong depletion of isotopes in rain water is seen at $2455 \mathrm{~m}$ a.s.l. (Fig. 13e). This is due to the steady large-scale ascent of 
20:00 UTC 15/10/2012

(a) Hourly precipitation

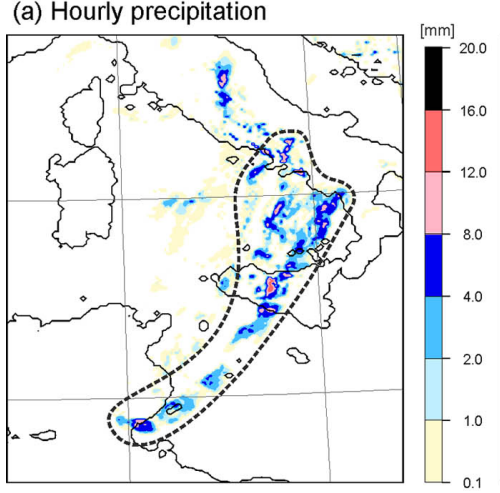

(b) $\delta 180 \mathrm{v}$

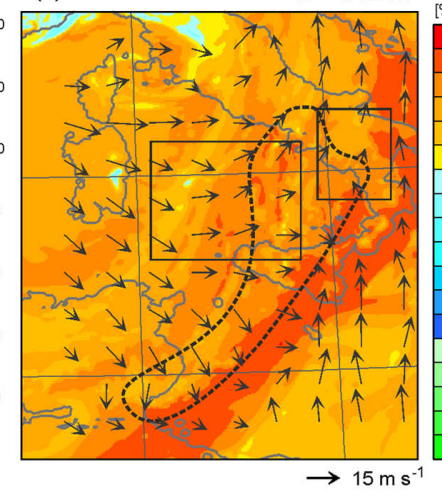

(d) $\delta 180 \mathrm{v}$

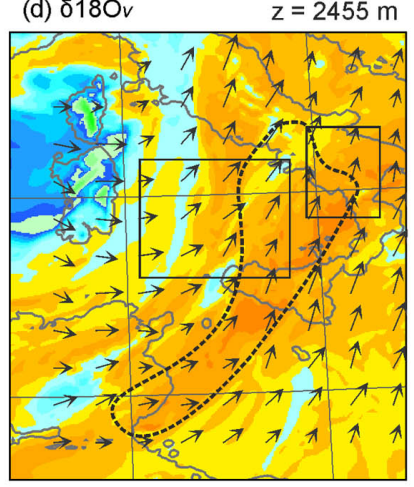

(f) $\delta 180 \mathrm{v}$

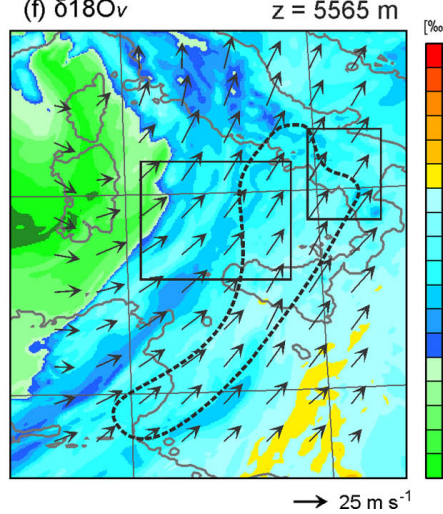

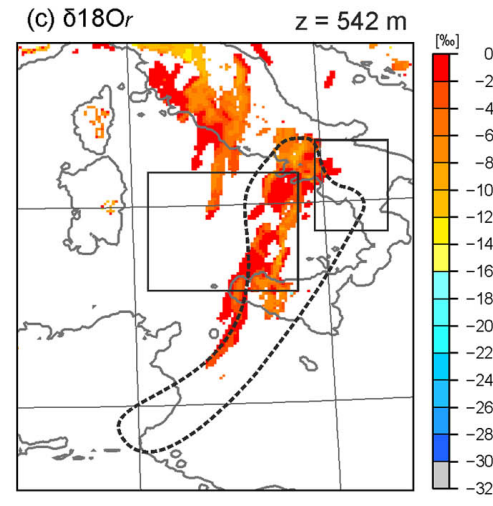

(e) $\delta 180 r \quad z=2455 m$

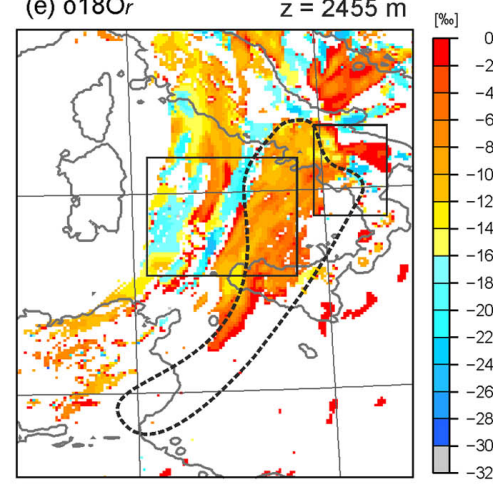

(g) $\delta 180 \mathrm{~s}$

$\mathrm{z}=5565 \mathrm{~m}$
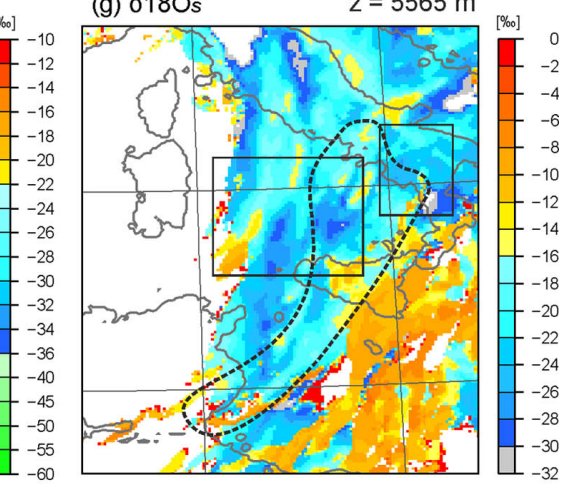

Figure 10. Horizontal distributions of (a) surface hourly precipitation (mm), $\delta^{18} \mathrm{O}_{\mathrm{v}}(\%$ ), at (b) model level 8 (about $542 \mathrm{~m}$ a.s.1.), (c) model level 16 (about $2455 \mathrm{~m}$ a.s.l.), and (d) model level 23 (about $5565 \mathrm{~m}$ a.s.1.), $\delta^{18} \mathrm{O}_{\mathrm{r}}\left(\%\right.$ ) at (e) $542 \mathrm{~m}$ a.s.l. and (f) $2455 \mathrm{~m}$ a.s.1., and $\delta^{18} \mathrm{O}_{\mathrm{s}}(\%$ ) at $5565 \mathrm{~m}$ a.s.1. at 20:00 UTC on 15 October 2012. Note that due to the terrain-following coordinates, the SWI values are partly depleted over the topography, e.g. in central Italy. The precipitating area is marked by the area enclosed by the dashed line.

air parcels in front of the trough that lead to cloud formation and rain out. The strong depletion of vapour in lower to middle altitudes is also evident from Fig. 5b, which shows decreasing $\delta^{18} \mathrm{O}_{\mathrm{v}}$ from 23:00 to 01:00 UTC (red to purple lines). It is worth noting that $\theta$ increases continuously until 23:00 UTC and reaches $327 \mathrm{~K}$ in SI (thin line with white circles in Fig. 5b), while $\theta$ is rather constant before the arrival of the front and trough, and the peak value is about $5 \mathrm{~K}$ lower in TY compared to SI (thin line with white circles in Fig. 5a, b). This reflects the influence of the African moisture plume including high $\delta^{18} \mathrm{O}_{\mathrm{v}}$ of vapour in excess of $-22 \%$, which is advected by the strong south-westerly flow from the Strait of Sicily to SI (Fig. 13d). This is consistent with the rapid reenrichment of vapour in SI after the precipitation (Fig. 5b). Then after 04:00 UTC, with the arrival of the front and upperlevel trough, the vapour decreases at all levels (Fig. 5b).

The Lagrangian analysis indicates that the moisture which feeds the convection during P2 is related to large-scale as- 

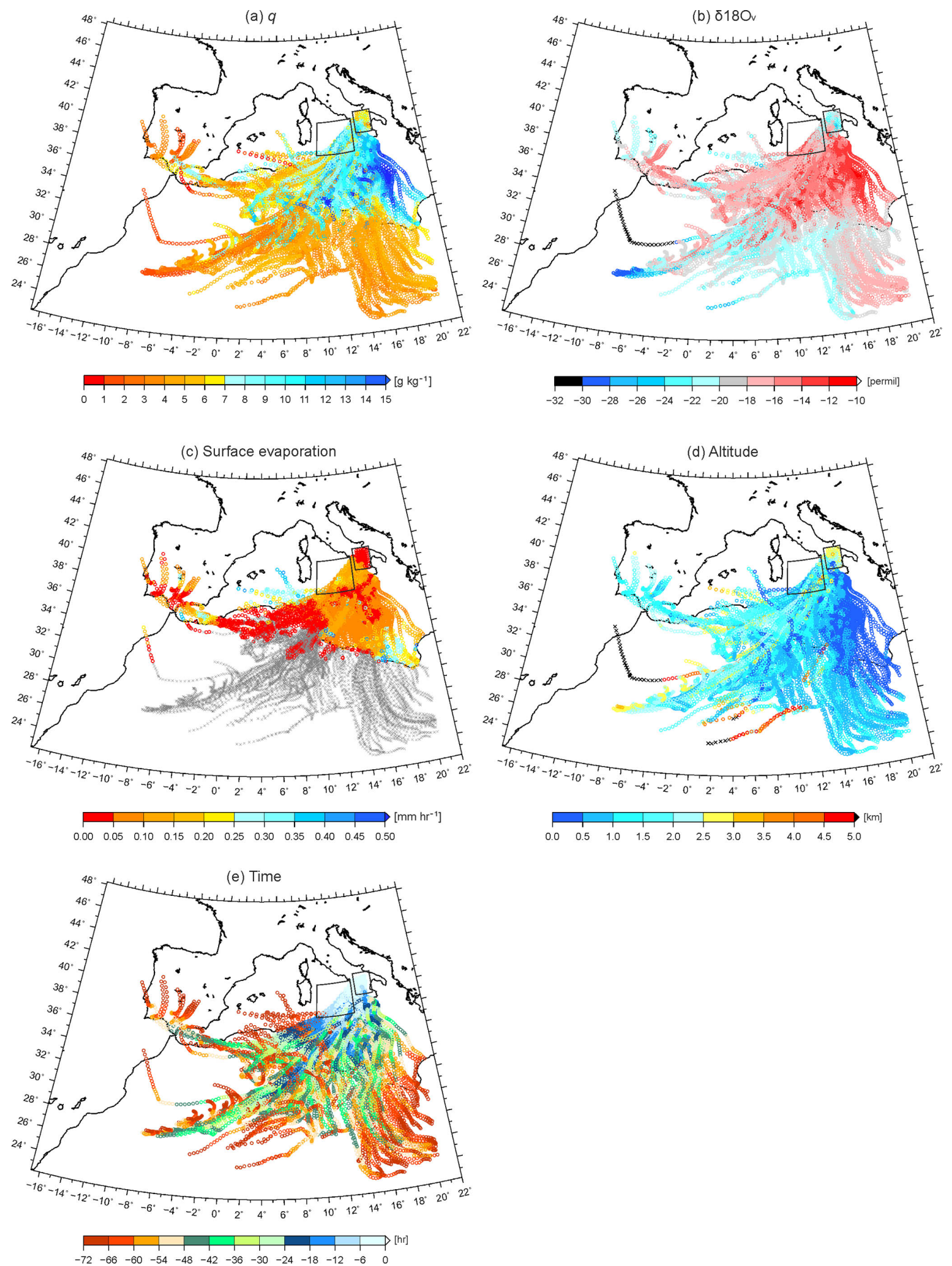

Figure 11. Same as Fig. 7 but for the air parcel arriving at SI in the 800-700 hPa layer at 00:00 UTC on 16 October 2012. 

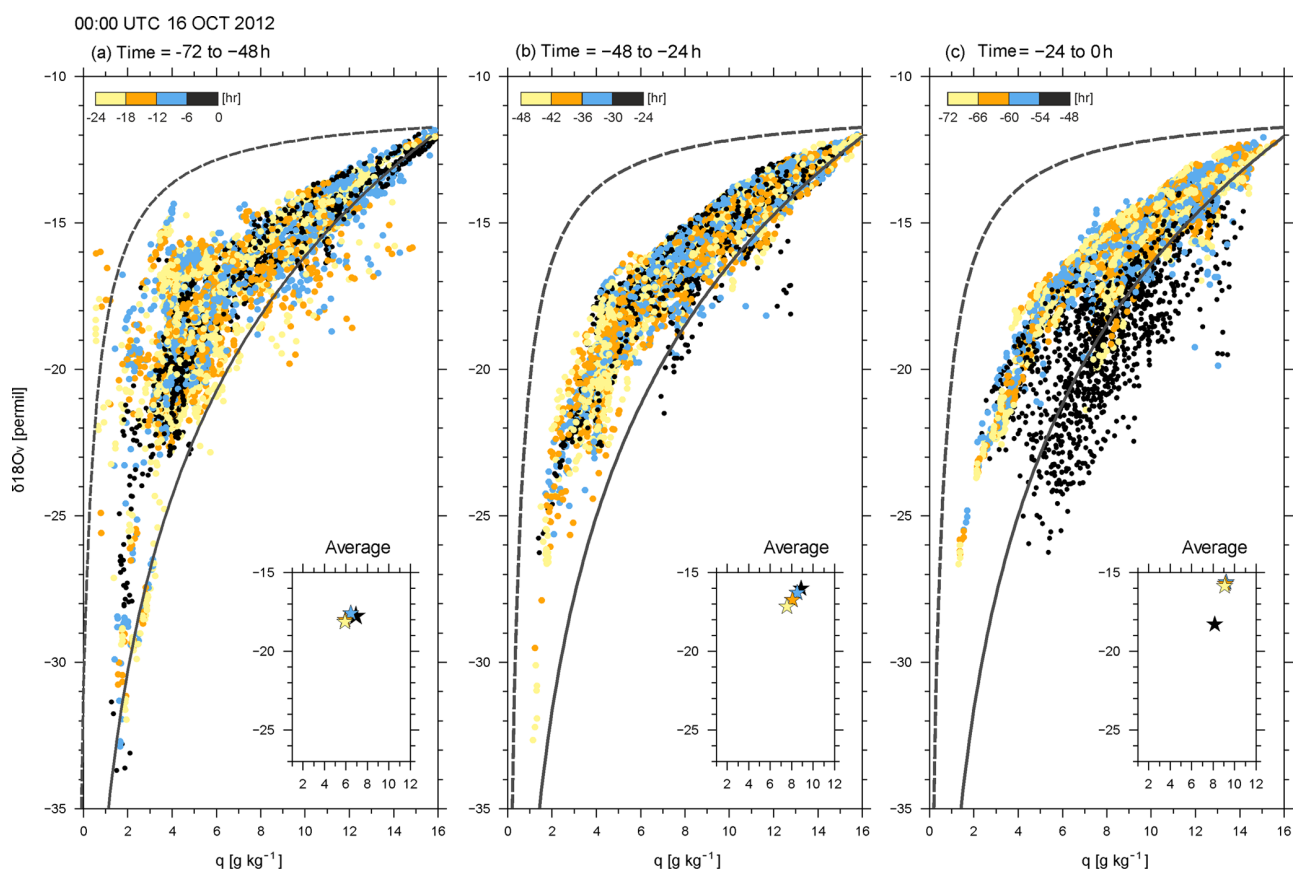

Figure 12. Scatter diagram of $q$ and $\delta^{18} \mathrm{O}_{\mathrm{v}}$ along the backward trajectories of Fig. 11 during (a) the times between -72 and $-48 \mathrm{~h},(\mathbf{b})$ times between -48 and $-24 \mathrm{~h}$, and (c) times between -24 and $0 \mathrm{~h}$ from 00:00 UTC on 16 October 2012 every $6 \mathrm{~h}$. The colour of dots changes every $6 \mathrm{~h}$. The mixing and Rayleigh lines are indicated by dashed and solid lines, respectively. The averaged $q$ and $\delta^{18} \mathrm{O}_{\mathrm{v}}$ every $6 \mathrm{~h}$ are displayed in the bottom right corner of each panel.

cent from north Africa, and the air parcels take up additional moisture (2-3 $\mathrm{g} \mathrm{kg}^{-1}$ ) over the Mediterranean. These air parcels carry moist and SWI-enriched air at layers below $2 \mathrm{~km}$ a.s.l. With the arrival of the upper-level trough over the southern Tyrrhenian Sea, strong cyclonic flow leads to the mixing of air from the African moisture plume to SI. During $\mathrm{P} 2$, the gradual depletion of water vapour takes place at SI at all levels.

\section{Conclusion}

On 15 to 16 October 2012, SI experiences a HPE (total precipitation of $62.4 \mathrm{~mm}$ ) with two phases of precipitation. The first one (P1) is induced by moist convection, while the second one (P2) is mainly associated with large-scale uplift along a front. The moisture transport and processes responsible for the HPEs that occurred over the SI area during IOP 13 have been analysed here using SWI data obtained from a numerical simulation with $\mathrm{COSMO}_{\text {iso }}$ at $7 \mathrm{~km}$ horizontal resolution. The main findings are summarized in two schematic illustrations (Fig. 14).

The $3 \mathrm{~d}$ backward trajectory analysis shows that the air parcels arriving in SI during P1 originate from the North Atlantic and descend within the upper-level trough over the north-western Mediterranean Sea. The SWI-depleted air mass within the descending air parcels rapidly takes up a large amount of water vapour from ocean evaporation (green encapsulated area in Fig. 14a) over the Tyrrhenian Sea and also from evaporated moisture from falling precipitation. Additional moisture is taken up over the Strait of Sicily from mixing with the enriched African moisture plume. The SWIenriched low-level air masses arriving upstream of SI are convectively pumped to higher altitudes, producing precipitation, and the SWI-depleted moisture is transported towards the surface within the downdrafts ahead of the cold front (red and blue arrows, Fig. 14a).

During P2 (Fig. 14b), just a few hours after P1, the origin of the air parcels arriving at SI is distinct, i.e. mostly from north Africa. The air parcels are moist and associated with large $\delta^{18} \mathrm{O}_{\mathrm{v}}$ (bottom-most arrow). With the arrival of the upper-level trough and mistral over the southern Tyrrhenian Sea, the strong cyclonic flow around the trough (grey dashed line in Fig. 14b) induces the advection of the African moisture plume towards SI and leads to large-scale uplift of the warm and moist air mass along the cold front. The existence of an African moisture plume is often associated with the presence of a deepening, north-south-oriented upper-level trough over the western Mediterranean (Chazette et al., 2015; Lee et al., 2016, 2017). It brings moisture and leads to gradual rain out of the air parcels over Italy. For the convective precipitation phase $(\mathrm{P} 1)$, most of the moisture processes producing the HPE take place during the last $18 \mathrm{~h}$ before the arrival over SI, while the large-scale advection of SWIenriched air mass in the African moisture plume by strong 
00:00 UTC 16/10/2012

(a) Hourly precipitation
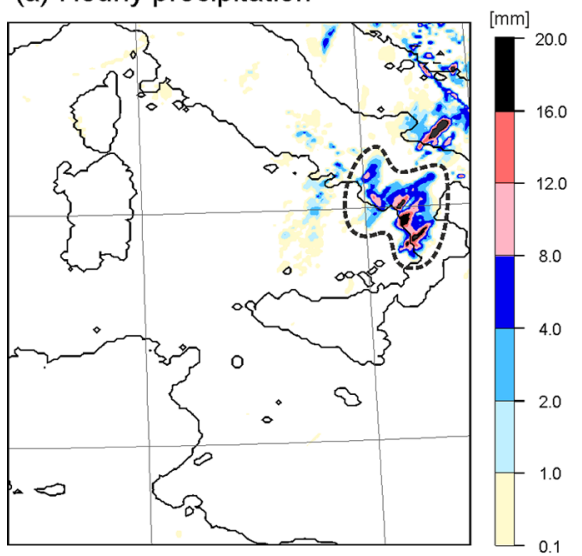

(b) $\delta 180 v$

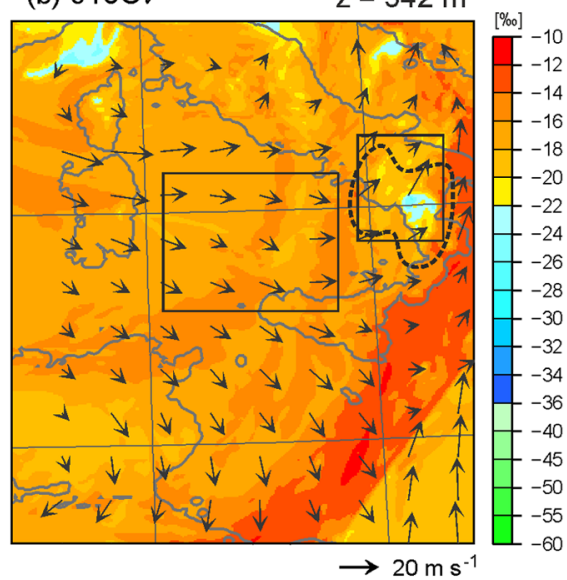

(d) $\delta 180 \mathrm{~V}$

$z=2455 \mathrm{~m}$

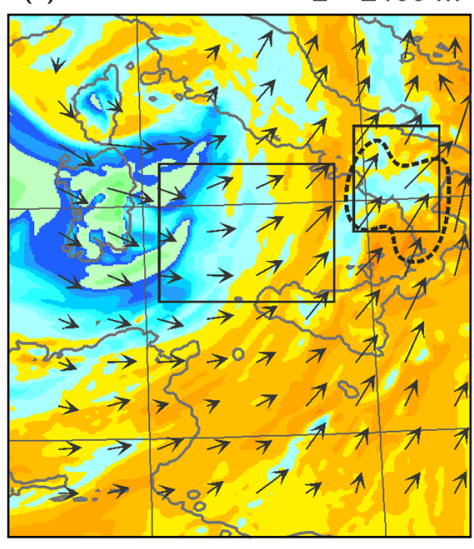

\section{(f) $\delta 180 \mathrm{v}$}

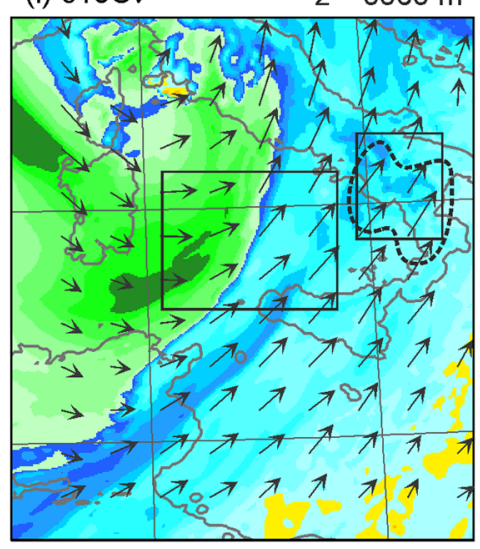

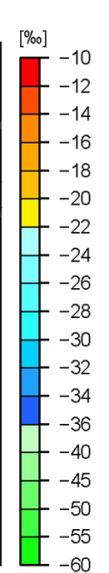

(c) $\delta 180 r$

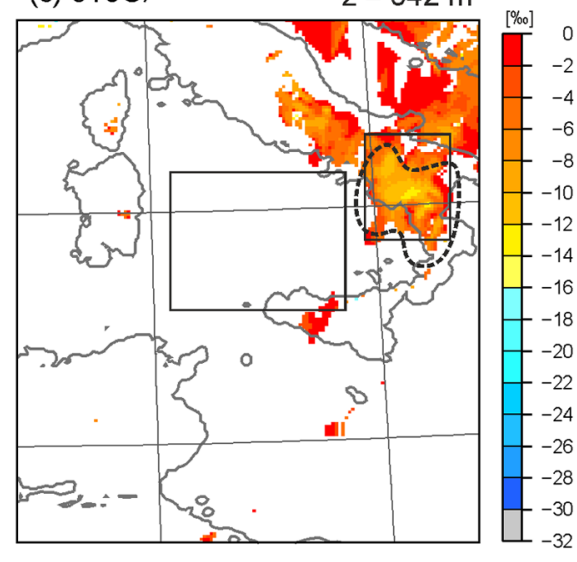

(e) $\delta 180 r$

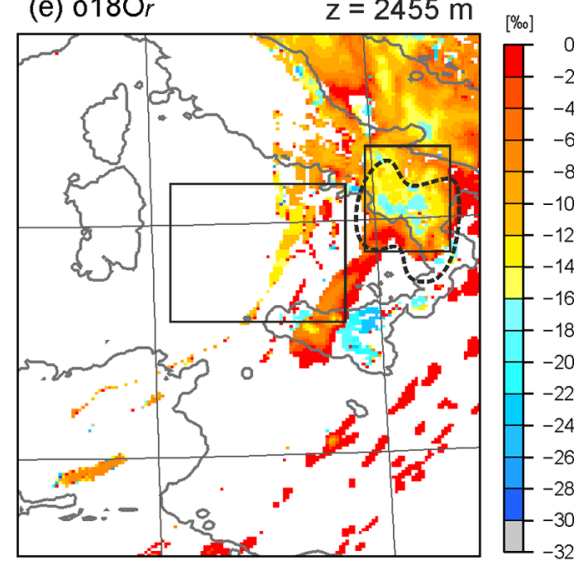

(g) $\delta 180 s$
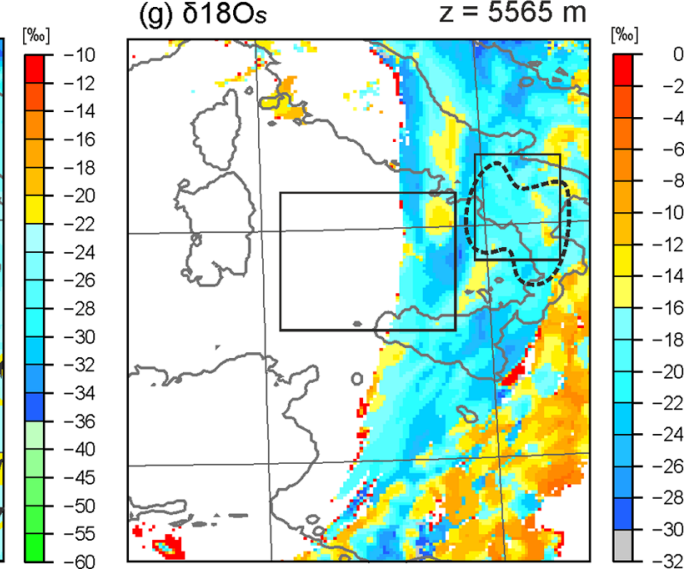

Figure 13. Same as Fig. 10 but for 00:00 UTC on 16 October 2012.

cyclonic flow lasts about $72 \mathrm{~h}$ during the large-scale precipitation phase (P2). In both phases, the air parcels take up a substantial amount of water vapour over the Mediterranean.

Using the hourly 3-D water vapour isotope data, we highlight the large variety of moisture sources and transport pathways that induced the two phases of the HPE in southern
Italy during IOP13 and the isotopic characteristics of various air masses associated with the upper-level trough, cold front, mistral, and African moisture plume that were involved in convection development. We also highlight the role of the upper-level trough over the southern Tyrrhenian Sea in driving the advection of the SWI-enriched plume from north 
(a) Convective precipitation phase

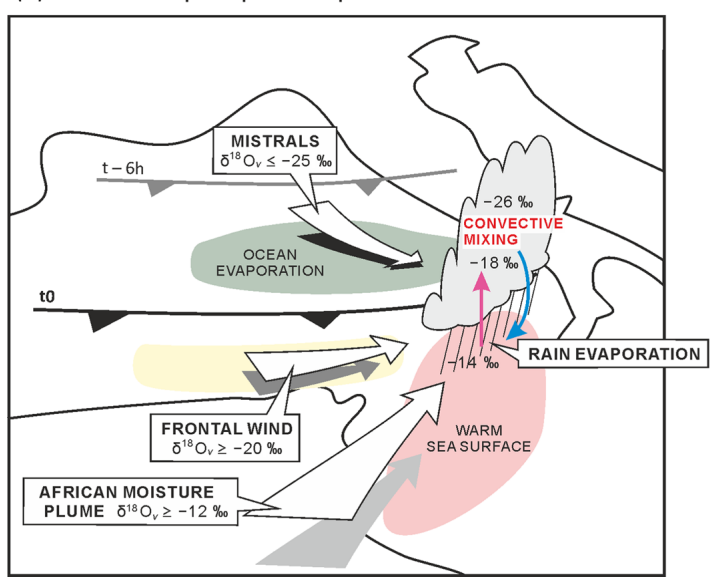

(b) Large-scale precipitation phase

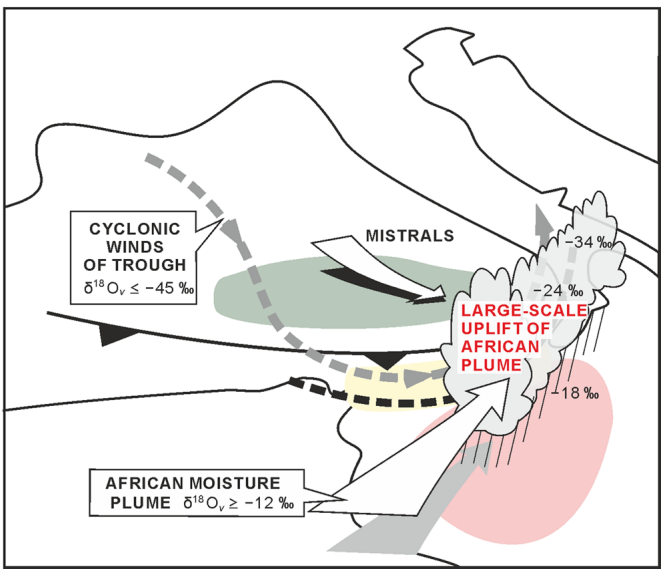

Figure 14. Schematics summarizing the main features of water vapour isotopologues and processes for deep convection upstream of SI and leading to Phase 1 (a) and Phase 2 (b) of the HPE. In (a) and (b), the white descending arrow indicates the mistral wind behind the edge of the cold front (thick black line). The white arrow in the yellow-shading-encapsulated area illustrates the frontal wind at $850 \mathrm{hPa}$, and the white arrow in the red-shading-encapsulated area (warm sea surface) indicates the elevated African moisture plume. In (a), convective ascent and precipitating downdraft are depicted by red and blue arrows, respectively. In (b), the southern edge of the upper trough is indicated by the dashed black line, and the cyclonic flow of the trough is indicated by the dashed grey line.

Africa into the region of the deep convective system, resulting in heavy precipitation over SI. Moreover, we demonstrate the importance of various moisture processes such as mixing, condensation, and re-evaporation along the pathway based on the $q-\delta$ analysis using 3-D SWI fields. Although our study is entirely based on a model simulation, the results suggest that the information on mesoscale moisture dynamical processes and moisture transport that is contained in SWIs, when combined with SWI observations, can provide very useful constrains on the representation of such processes in numerical models.

Our study is the first study to investigate the potential benefit of SWIs in the context of a HPE in the Mediterranean. As such, our study provides a proof of concept of the usefulness of SWI data to understand the variety of origins and moisture processes associated with air masses feeding the convection over SI. This will be further investigated in future research using SWI measurements obtained from various platforms, e.g. ground-based, near-surface, airborne (Sodemann et al., 2017), and space-borne. Our modelling study will also allow forthcoming tailored field campaigns in the Mediterranean region to be designed. To further study the details of the fractionation processes in and around deep convective systems, complementary investigations will be conducted using higher-resolution convection-permitting simulation with a $2 \mathrm{~km}$ grid to shed light on cloud microphysical processes inside deep convection.

Data availability. COSMOiso output data are available from the authors upon request (keun-ok.lee@ aero.obs-mip.fr).
Author contributions. KOL, FA, SP, and CF planned the paper and analyses. SP and KOL designed the numerical simulation, and SP performed it. JLL and JPC contributed to the discussion of the results. KOL prepared the paper with contributions from all coauthors.

Competing interests. The authors declare that they have no conflict of interest.

Special issue statement. This article is part of the special issue "Hydrological cycle in the Mediterranean (ACP/AMT/GMD/HESS/NHESS/OS inter-journal SI)". It is not associated with a conference.

Acknowledgements. We thank Jean-Pierre Pinty (Laboratoire d'Aerologie) for insightful suggestions and three anonymous reviewers for their interesting comments and suggestions. This work was supported by the French Agence Nationale de la Recherche (ANR) via the IODA-MED grant ANR-11-BS56-0005, the MUSIC grant ANR-14-CE01-014, and the MISTRALS/HyMeX programme.

Financial support. This research has been supported by the French Agence Nationale de la Recherche (ANR) (the IODA-MED grant no. ANR-11-BS56-0005 and the MUSIC grant no. ANR-14-CE01014) and the MISTRALS/HyMeX programme.

Review statement. This paper was edited by Christian Barthlott and reviewed by three anonymous referees. 


\section{References}

Aemisegger, F. and Papritz, L.: A climatology of strong large-scale ocean evaporation event. Part I: Identification, global distribution, and associated climate conditions, J. Climate, 31, 72877312, https://doi.org/10.1175/JCLI-D-17-0591.1, 2018.

Aemisegger, F., Spiegel, J. K., Pfahl, S., Sodemann, H., Eugster, W., and Wernli, H.: Isotope meteorology of cold front passages: A case study combining observations and modelling, Geophys. Res. Lett., 42, 5652-5660, https://doi.org/10.1002/2015GL063988, 2015.

Aemisegger, F. and Sjolte, J.: A climatology of strong large-scale ocean evaporation event. Part II: Relevance for the deuterium excess signature of the evaporation flux, J. Climate, 31, 7313-7336, https://doi.org/10.1175/JCLI-D-17-0592.1, 2018.

Barthlott, C. and Davolio, S.: Mechanisms initiating heavy precipitation over Italy during the HyMeX Special Observation Period 1: A numerical case study using two mesoscale models, Q. J. Roy. Meteor. Soc., 142, 238-258, https://doi.org/10.1002/qj.2630, 2015.

Blossey, P. N., Huang, Z., and Romps, D. M.: Isotopic composition of water in the tropical tropopause layer in cloud-resolving simulations of an idealized tropical circulation, J. Geophys. Res., 115, D24309, https://doi.org/10.1029/2010JD014554, 2010.

Bonne, J.-L., Masson-Delmotte, V., Cattani, O., Delmotte, M., Risi, C., Sodemann, H., and Steen-Larsen, H. C.: The isotopic composition of water vapour and precipitation in Ivittuut, southern Greenland, Atmos. Chem. Phys., 14, 4419-4439, https://doi.org/10.5194/acp-14-4419-2014, 2014.

Chazette, P., Flamant, C., Raut, J. C., Totems, J., and Shang, X.: Tropical moisture enriched storm tracks over the Mediterranean and their link with intense rainfall in the Cevennes-Vivarais area during HyMeX, Q. J. Roy. Meteor. Soc., 142, 320-334, https://doi.org/10.1002/qj.2674, 2015.

Christner, E., Aemisegger, F., Pfahl, S., Werner, M., Cauquoin, A., Schneider, M., Hase, F., Barthlott, S., and Schädler, G.: The climatological impacts of continental surface evaporation, rainout, and subcloud processes on $\delta \mathrm{D}$ of water vapor and precipitation in Europe, J. Geophys. Res.-Atmos., 123, 4390-4409, https://doi.org/10.1002/2017JD027260, 2018.

Davies, H. C.: A lateral boundary formulation for multi-level prediction models, Q. J. Roy. Meteor. Soc., 102, 405-418, 1976.

Dessler, A. E. and Sherwood, S. C.: A model of HDO in the tropical tropopause layer, Atmos. Chem. Phys., 3, 2173-2181, https://doi.org/10.5194/acp-3-2173-2003, 2003.

Doms, G., Förstner, J., Heise, E., Herzog, H. J., Raschendorfer, M., Schrodin, R., Reinhardt, T., and Vogel, G.: A description of the nonhydrostatic regional model LM. Part II: Physical parameterization, Deutscher Wetterdienst, Offenbach, Germany, 2005.

Ducrocq, V., Braud, I., Davolio, S., Ferretti, R., Flamant, C., Jansa, A., Kalthoff, N., Richard, E., Taupier-Letage, I., Ayral, P. A., Belamari, S., Berne, A., Borga, M., Boudevillain, B., Bock, O., Boichard, J. L., Bouin, M. N., Bousquet, O., Bouvier, C., Chiggiato, J., Ciimini, D., Corsmeier, U., Coppola, L., Cocquerez, P., Defer, E., Delanoë, J., Di Girolamo, P., Doerenbecher, A., Drobinski, P., Dufournet, Y., Fourrié, N., Gourley, J. J., Labatut, L., Lambert, D., Le Coz, J., Marzano, F. S., Molinié, G., Montani, A., Nord, G., Nuret, M., Ramage, K., Rison, W., Roussot, O., Said, F., Schwarzenboeck, A., Testor, P., Van Baelen, J., Vincendon, B., Aran, M., and Tamayo, J.: HyMeX-SOP1:
The Field Campaign Dedicated to Heavy Precipitation and Flash Flooding in the Northwestern Mediterranean, B. Am. Meteorol. Soc., 95, 1083-1100, https://doi.org/10.1175/BAMS-D-1200244.1, 2014.

Duffourg, F. and Ducrocq, V.: Assessment of the water supply to Mediterranean heavy precipitation: A method based on finely designed water budgets, Atmos. Sci. Lett., 14, 133-138, 2013.

Duffourg, F., Lee, K. O., Ducrocq, V., Flamant, C., Chazette, P., and Girolamo, P. D.: Role of moisture patterns in the backbuilding formation of HyMeX IOP13 heavy precipitation system, Q. J. Roy. Meteor. Soc., 144, 291-303, https://doi.org/10.1002/qj.3201, 2018.

Dütsch, M., Pfahl, S., Meyer, M., and Wernli, H.: Lagrangian process attribution of isotopic variations in near-surface water vapour in a 30-year regional climate simulation over Europe, Atmos. Chem. Phys., 18, 1653-1669, https://doi.org/10.5194/acp18-1653-2018, 2018.

Galewsky, J. and Hurley, J. V.: An advection-condensation model for subtropical water vapor isotopic ratios, J. Geophys. Res., 115, D16116, https://doi.org/10.1029/2009JD013651, 2010.

Galewsky, J., Steen-Larsen, H. C., Field, R. D., Worden, J., Risi, C., and Schneider, M.: Stable isotopes in atmospheric water vapor and applications to the hydrologic cycle, Rev. Geophys., 54, 809865, https://doi.org/10.1002/2015RG000512, 2016.

Jacob, J. and Sonntag, C.: An 8-year record of the seasonal variation of ${ }^{2} \mathrm{H}$ and ${ }^{18} \mathrm{O}$ in atmospheric water vapour and precipitation at Heidelberg, Germany, Tellus B, 43, 291-300, https://doi.org/10.1034/j.1600-0889.1991.t01-2-00003.x, 1991.

Jaussaume, J., Sadourny, R., and Jouzel, J.: A general circulation model of water isotope cycles in the atmosphere, Nature, 311, 24-29, 1984.

Jouzel, J., Masson-Delmotte, V., Stiévenard, M., Landais, A., Vimeux, F., and Johnsen S. J.: Sveinbjornsdottir and White J.W.C., Rapid deuterium excess changes in Greenland ice cores: a link between the ocean and the atmosphere, CRAS, 337, 957969, 2005.

Lacour, J.-L., Flamant, C., Risi, C., Clerbaux, C., and Coheur, P.-F.: Importance of the Saharan heat low in controlling the North Atlantic free tropospheric humidity budget deduced from IASI $\delta$ D observations, Atmos. Chem. Phys., 17, 9645-9663, https://doi.org/10.5194/acp-17-9645-2017, 2017.

Lee, K. O., Flamant, C., Ducrocq, V., Duffourg, F., Fourrié, N., and Davolio, S.: Convective initiation and maintenance processes of two back-building mesoscale convective systems leading to heavy precipitation events in Southern Italy during HyMeX IOP 13, Q. J. Roy. Meteor. Soc., 142, 2623-2635, https://doi.org/10.1002/qj.2978, 2016.

Lee, K. O., Flamant, C., Ducrocq, V., Duffourg, F., Fourrié, N., Delanoë, J., and Bech, J.: Initiation and development of a mesoscale convective system in the Ebro River Valley and related heavy precipitation over northeastern Spain during HyMeX IOP15a, Q. J. Roy. Meteor. Soc., 143, 942-956, https://doi.org/10.1002/qj.2851, 2017.

Lee, K.-O., Flamant, C., Duffourg, F., Ducrocq, V., and Chaboureau, J.-P.: Impact of upstream moisture structure on a back-building convective precipitation system in south-eastern France during HyMeX IOP13, Atmos. Chem. Phys., 18, 1684516862, https://doi.org/10.5194/acp-18-16845-2018, 2018. 
Lin, Y. L., Chiao, S., Wang, T. A., Kaplan, M. L., and Weglarz, R. P.: Some common ingredients for heavy orographic rainfall, Weather Forecast., 16, 633-660, 2001.

Martius, O., Zenklusen, E., Schwierz, C., and Davies, H. C.: Episodes of Alpine heavy precipitation with an overlying elongated stratospheric intrusion: A climatology, Int. J. Climatol., 26, 1149-1164, https://doi.org/10.1002/joc.1295, 2006.

Noone, D.: The influence of midlatitude and tropical overturning circulation on the isotopic composition of atmospheric water vapor and Antarctic precipitation, J. Geophys. Res., 113, D04102, https://doi.org/10.1029/2007JD008892, 2008.

Noone, D.: Pairing measurement of the water vapor isotope ratio with humidity to deduce atmospheric moistening and dehydration in the tropical midtroposphere, J. Climate, 25, 4476-4494, https://doi.org/10.1175/JCLI-D-11-00582.1, 2012.

Nuissier, O., Ducrocq, V., Ricard, D., Lebeaupin, C., and Anquetin, S.: A numerical study of three catastrophic precipitating events over southern France. I: Numerical framework and synoptic ingredients, Q. J. Roy. Meteor. Soc., 134, 111-130, 2008.

Nuissier, O., Joly, B., Joly, A., Ducrocq, V., and Arbogast, P.: A statistical downscaling to identify the large-scale circulation patterns associated with heavy precipitation events over southern France, Q. J. Roy. Meteor. Soc., 137, 1812-1827, https://doi.org/10.1002/qj.866, 2011.

Pfahl, S. and Wernli, H.: Air parcel trajectory analysis of stable isotopes in water vapor in the eastern Mediterranean, J. Geophys. Res., 113, D20104, https://doi.org/10.1029/2008JD009839, 2008.

Pfahl, S., Wernli, H., and Yoshimura, K.: The isotopic composition of precipitation from a winter storm - a case study with the limited-area model COSMOiso, Atmos. Chem. Phys., 12, 16291648, https://doi.org/10.5194/acp-12-1629-2012, 2012.

Ricard, D., Ducrocq, V., and Auger, L.: A climatology of the mesoscale environment associated with heavily precipitating events over a northwestern mediterranean area, J. Appl. Meteorol. Clim., 51, 468-488, https://doi.org/10.1175/JAMC-D-11017.1, 2012.

Risi, C., Bony, S., and Vimeux, F.: Influence of convective processes on the isotopic composition $\left(\delta^{18} \mathrm{O}\right.$ and $\left.\delta \mathrm{D}\right)$ of precipitation and water vapour in the Tropics: Part 2: Physical interpretation of the amount effect, J. Geophys. Res., 113, D19306, https://doi.org/10.1029/2008JD009943, 2008.

Risi, C., Bony, S., Vimeux, F., Chong, M., and Descroix, L.: Evolution of the water stable isotopic composition of the rain sampled along Sahelian squall lines, Q. J. Roy. Meteor. Soc., 136, $227-$ 242, https://doi.org/10.1002/qj.485, 2010.

Röhner, L., Nerding, K.-U., and Corsmeier, U.: Diagnostic study of a HyMeX heavy precipitation event over Spain by investigation of moisture trajectories, Q. J. Roy. Meteor. Soc., 142, 287-297, https://doi.org/10.1002/qj.2825, 2016.

Schneider, M., Wiegele, A., Barthlott, S., González, Y., Christner, E., Dyroff, C., García, O. E., Hase, F., Blumenstock, T., Sepúlveda, E., Mengistu Tsidu, G., Takele Kenea, S., Rodríguez, S., and Andrey, J.: Accomplishments of the MUSICA project to provide accurate, long-term, global and high-resolution observations of tropospheric $\{\mathrm{H} 2 \mathrm{O}, \delta \mathrm{D}\}$ pairs - a review, Atmos. Meas. Tech., 9, 2845-2875, https://doi.org/10.5194/amt-9-2845-2016, 2016.
Sherwood, S. and Dessler, A.: On the control of stratospheric humidity, Geophys. Res. Lett., 27, 2513-2516, 2000.

Sodemann, H., Aemisegger, F., Pfahl, S., Bitter, M., Corsmeier, U., Feuerle, T., Graf, P., Hankers, R., Hsiao, G., Schulz, H., Wieser, A., and Wernli, H.: The stable isotopic composition of water vapour above Corsica during the HyMeX SOP1 campaign: insight into vertical mixing processes from lowertropospheric survey flights, Atmos. Chem. Phys., 17, 6125-6151, https://doi.org/10.5194/acp-17-6125-2017, 2017.

Sprenger, M. and Wernli, H.: The LAGRANTO Lagrangian analysis tool - version 2.0, Geosci. Model Dev., 8, 2569-2586, https://doi.org/10.5194/gmd-8-2569-2015, 2015.

Steen-Larsen, H. C., Sveinbjörnsdottir, A. E., Peters, A. J., MassonDelmotte, V., Guishard, M. P., Hsiao, G., Jouzel, J., Noone, D., Warren, J. K., and White, J. W. C.: Climatic controls on water vapor deuterium excess in the marine boundary layer of the North Atlantic based on 500 days of in situ, continuous measurements, Atmos. Chem. Phys., 14, 7741-7756, https://doi.org/10.5194/acp-14-7741-2014, 2014.

Steppeler, J., Doms, G., Schättler, U., Bitzer, H. W., Gassmann, A., Damrath, U., and Gregoric, G.: Meso-gamma scale forecast using the nonhydrostatic model LM, Meteorol. Atmos. Phys., 82, 75-96, 2003.

Sturm, K., Hoffmann, G., Langmann, B., and Stichler, W. Simulation of $\delta^{18} \mathrm{O}$ in precipitation by the regional circulation model REMOiso, Hydrol. Process, 19, 3425-3444, https://doi.org/10.1002/hyp.5979, 2005.

Tiedtke, M.: A comprehensive mass flux scheme for cumulus parameterization in large-scale models, Mon. Weather Rev., 117, 1779-1800, 1989.

Tremoy, G., Vimeux, F., Soumana, S., Souley, I., Risi, C., Favreau, G., and Oi, M.: Clustering mesoscale convective systems with laser-based water vapor $\delta^{18} \mathrm{O}$ monitoring in Niamey (Niger), J. Geophys. Res., 119, 5079-5103, https://doi.org/10.1002/2013jd020968, 2014.

Turato, B., Reale, O., and Siccardi, F.: Water vapour sources of the October 2000 Piedmont flood, J. Hydrometeorol., 5, 693-712, https://doi.org/10.1175/15257541(2004)005<0693:WVSOTO>2.0.CO;2, 2004.

Vimeux, F., Masson, V., Jouzel, J., Petit, J., Steig, E., Stievenard, M., Vaikmae, R., and White, J. W. C.: Holocene hydrological cycle changes in southern hemisphere documented in Antarctic deuterium excess records, Clim. Dynam., 17/7, 503-513, 2001.

Wernli, H. and Davies, H. C.: A Lagrangian-based analysis of extratropical cyclones. I: The method and some applications, Q. J. Roy. Meteor. Soc, 123, 467-489, 1997.

Winschall, A., Pfahl, S., Sodemann, H., and Wernli, H.: Impact of north Atlantic evaporation hot spots on southern Alpine heavy precipitation events, Q. J. Roy. Meteor. Soc., 138, 1245-1258, https://doi.org/10.1002/qj.987, 2012.

Winschall, A., Sodemann, H., Pfahl, S., and Wernli, H.: How important is intensified evaporation for Mediterranean precipitation extremes?, J. Geophys. Res.-Atmos., 119, 5240-5256, 2014.

Worden, J., Noone, D., Bowman, K., and Beer, R.: Importance of rain evaporation and continental convection in the tropical water cycle, Nature, 445, 528-532, 2007. 
Yoshimura, K., Kanamitsu, M., Noone, D., and Oki, T.: Historical isotope simulation using Reanalysis atmospheric data, J. Geophys. Res., 113, D19108, https://doi.org/10.1029/2008JD010074, 2008.
Yoshimura, K., Kanamitsu, M., and Dettinger, M.: Regional downscaling for stable water isotopes: A case study of an atmospheric river event, J. Geophys. Res., 115, D18114, https://doi.org/10.1029/2010JD014032, 2010. 